\begin{tabular}{l} 
Bentham OPEN \\
\hline CrossMark \\
\hline Content list available at: www.benthamopen.com/TODENTJ/ \\
DOI: $10.2174 / 1874210601610010664$
\end{tabular}

REVIEW ARTICLE

\title{
The Effect of Chin-cup Therapy in Class III Malocclusion: A Systematic Review
}

\author{
Sophia Mousoulea ${ }^{1, *}$, Ioannis Tsolakis ${ }^{2}$, Efstratios Ferdianakis ${ }^{3}$ and Apostolos I. Tsolakis ${ }^{3}$

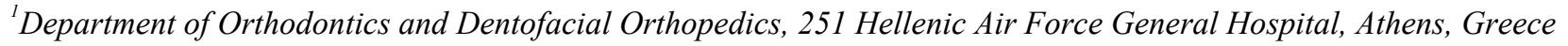 \\ ${ }^{2}$ Laboratory for Experimental Surgery and Surgical Research "N. S. Christeas", Medical School, University of Athens, \\ Greece \\ ${ }^{3}$ Department of Orthodontics, School of Dentistry, University of Athens, Greece
}

Received: March 05, 2016

Revised: September 07, 2016

Accepted: October 28, 2016

\begin{abstract}
:
Background:

The treatment of Class III malocclusion has been challenging for orthodontists. Among a plethora of treatment modalities, the chincup is considered a traditional appliance for early orthopedic intervention.
\end{abstract}

\section{Objective:}

The present study aims to investigate the current scientific evidence regarding the effectiveness of chin-cup therapy in Class III malocclusion of prognathic growing patients.

\section{Method:}

A systematic review of the literature was conducted using PubMed/Medline and the Cochrane Central Register of Controlled Trials from January 1954 to October 2015. Articles were selected based on established inclusion/ exclusion criteria.

\section{Results:}

The search strategy resulted in 3285 articles. 14 studies were selected for the final analysis. They were all CCTs, 13 of retrospective and 1 of prospective design. Methodological quality was evaluated by a risk of bias assessment, as suggested by the Cochrane Risk of Bias Assessment Tool for Non-Randomized Studies on Interventions. The reported evidence presented favorable short-term outcomes both in hard and soft tissues improving the Class III profile, as well as desirable dento-alveolar changes, positively affecting the Class III malocclusion.

\section{Conclusion:}

There is considerable agreement between studies that chin-cup therapy can be considered for the short-term treatment of growing patients with Class III malocclusion, as indicated by favorable changes both in the hard and soft tissues. The existence of considerable risk of bias in all selected studies and the unclear long-term effectiveness of chin-cup therapy highlight the need for further investigation to draw reliable conclusions.

Keywords: Chin-cup Therapy, Class III Malocclusion, Class III Treatment, Mandibular Prognathism, Skeletal Malocclusion, Systematic Review.

\section{INTRODUCTION}

Skeletal Class III malocclusion is clinically presented as a result of maxillary retrusion, mandibular protrusion or a

\footnotetext{
* Address correspondence to this author at the Department of Orthodontics and Dentofacial Orthopedics, 251 Hellenic Air Force General Hospital, Athens, Greece; Tel: +306973277463; E-mail: sophia.mousoulea@gmail.com
} 
combination of the two [1 - 3]. It is often associated with complex dento-alveolar problems, which include an anterior edge-to-edge relation or anterior and/or posterior crossbite [4]. Patients with Class III malocclusion exhibit potential esthetic problems presenting a concave profile, and a vertical function pattern [3,4], which limits their function to vertical movements.

The prevalence of Class III malocclusion presents a wide variety among and within populations [5, 6], as declared by a high $23 \%$ rate in Asian populations contrasted to a smaller 5\% rate in Caucasians [1, 7]. Treatment of Class III malocclusion has been a challenge for orthodontists [1]. Among various treatment modalities, the chin-cup is considered a traditional appliance for the early orthopedic management of prognathic growing patients [2, 8 - 11]. Its clinical effectiveness has been investigated over the years with many studies confirming a general improvement of Class III malocclusion through backward and downward mandibular rotation, retardation of mandibular growth, remodeling of the mandible and the temporomandibular joint (TMJ), retroclination of mandibular incisors and closing of the gonial angle $[1,2,7,10,11]$.

Despite the plethora of the available evidence, clinical results achieved with the chin-cup constitute a controversial issue among researchers. Owing to the absence of a standard protocol concerning the chin-cup's appropriate use and the contradicting results of the reported outcomes and outcomes measures, a clear interpretation of data is not possible [1, 2, $7,12]$. Although a great number of studies focus on the skeletal and dento-alveolar changes [2, 7, 10 - 12], the effects of chin-cup therapy on facial soft tissues remain uninvestigated. Furthermore, the vast majority of studies report outcomes of the chin-cup use obtained over a short-term period $[2,7,10,12]$, while there is a lack of studies examining the longterm effectiveness of chin-cup therapy.

For the aforementioned reasons the purpose of the present systematic review is the investigation of the short- and long-term effects on both the hard and soft tissues induced by chin-cup therapy in the Class III malocclusion of growing patients, based on the existing scientific evidence.

\section{MATERIALS AND METHODOLOGY}

\section{Type of Participants}

Prognathic growing patients (pre-pubertal, pubertal) with Class III malocclusion receiving chin-cup therapy for the improvement of their skeletal, dento-alveolar and facial characteristics.

\section{Type of Interventions}

Chin-cups. (Potential confounders and co-interventions were specified and taken into account).

\section{Comparisons}

No treatment.

\section{Outcomes}

-Primary: Skeletal, dento-alveolar and soft-tissue effects of chin-cup therapy.

-Secondary: Short and long-term effectiveness of chin-cup therapy, if provided, in order to assess the stability of the results.

All reported time-points after the completion of the treatment, judged by the authors of the trials were included. The short-term effectiveness is related to the outcomes obtained upon the end of the active treatment with chin-cup therapy, while the long-term effectiveness is related to the ones obtained at a post-treatment observation after the end of the active treatment.

\section{Search Strategy}

A literature search was carried out by applying the Medline database (PubMed www.ncbi.nih.gov) and the Cochrane Central Register of Controlled Trials covering the period from January 1954 to October 2015 and using the following Medical Subject Heading (MeSH) terms; "Malocclusion, Angle Class III”, "chin-cup therapy", “chincap therapy", (Table 1). A schematic representation of the search strategy is shown in Fig. (1). 
Table 1. Search strategy.

\begin{tabular}{|c|c|}
\hline MeSH Terms & Articles Retrieved \\
\hline "Malocclusion, Angle Class III" & $\mathbf{3 2 0 8}$ articles \\
\hline "Chin-cup therapy" & $\mathbf{5 3}$ articles \\
\hline "Chincap therapy" & 24 articles \\
\hline
\end{tabular}

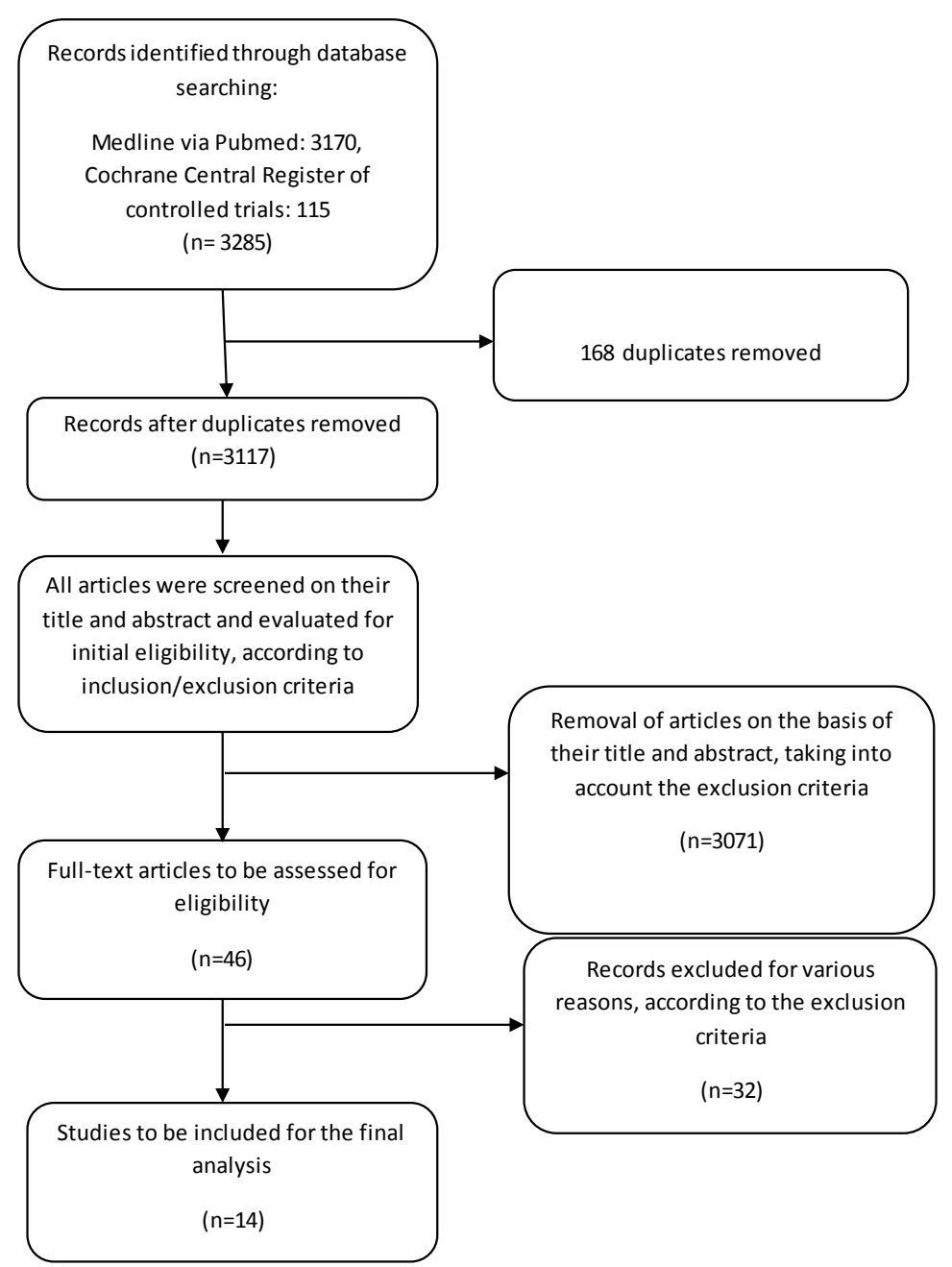

Fig. (1). Flow diagram of the literature search process.

\section{Selection Criteria}

Articles selected for this study fulfilled the criteria for inclusion, (Table 2). The criteria included randomized clinical trials (RCTs), prospective and retrospective clinical trials (CCTs) with untreated control groups. The retrieved studies had to use cephalometrics for analyzing the effects of chin-cup therapy contrasted to untreated Class III control groups. Table 2 also presents in detail the exclusion criteria.

Table 2. Inclusion-exclusion criteria.

\begin{tabular}{|c|c|}
\hline Inclusion Criteria & Exclusion Criteria \\
\hline 1. Articles published from January 1954 to October 2015 & 1. Reviews and Meta-analysis \\
\hline 2. RCTs & 2. Case reports/case series \\
\hline 3. Prospective-Retrospective CCTs & 3. Studies on adults \\
\hline 4. Studies on growing patients & 4. Treatment combined with extractions \\
\hline 5. Studies based on lateral cephalograms & 5. Treatment combined with surgery \\
\hline 6. Articles in English & 6. Studies about the relationship between Class III and TMJ disorders \\
\hline
\end{tabular}


(Table $\square$ ) contd......

\begin{tabular}{|l|c|}
\hline Inclusion Criteria & Exclusion Criteria \\
\hline & 7. Laboratory studies \\
\hline & 8. Commentary/Opinion articles \\
\hline & 9. Abstracts \\
\hline & 10. Articles, whose objective is out of the scope of interest of the present study \\
\hline
\end{tabular}

\section{Data Extraction}

Two independent reviewers (SM, EF) made the assessment of the articles individually in predefined data extraction forms. No blinding to the authors during data extraction was made and any inter-examiner conflicts were resolved by discussion with a third reviewer (IT). The same reviewers performed the risk of bias assessment of the articles, with one author (AT) acting as the coordinator.

\section{Quality Analysis}

For the qualitative evaluation of the retrieved studies the risk of bias was assessed by two reviewers (SM, EF) independently. The assessment was based on the following tool: A Cochrane Risk of Bias Assessment Tool for NonRandomized Studies on Interventions (ACROBAT-NRSI) [13]. This tool addresses seven domains of bias; bias due to confounding, bias in selection of participants into the study, bias in measurement of interventions, bias due to departures from intended intervention, bias due to missing data, bias in measurement of outcomes and bias in selection of the reported result.

Important confounders with regard to chin-cup therapy were considered those that could have an impact on the reported results. Thus, the following confounders were taken into account both for patients and controls: ethnicity (as Asian populations have a higher prevalence of Class III malocclusion) [1, 7,14 - 16], age in relation to the skeletal maturity stage, pre-treatment skeletal Class of malocclusion (when it was not skeletal Class III both for patients and controls), soft-tissue profile individual variation in thickness and in tension, and pre-treatment overjet. Moreover, cointerventions were considered the use of additional appliances, such as an occlusal bite plate, a quad-helix appliance, a lingual arch, etc., and the utilization of force magnitude of the chin-cup traction.

Three different outcomes were investigated; skeletal, dento-alveolar and soft-tissue effects of chin-cup therapy in Class III malocclusion both in the short- and in the long-term. For every different outcome of each study an initial risk of bias for every domain was assessed, as indicated by the ACROBAT-NRSI [13]. Because same issues applied to all outcomes, a grouped assessment was made. Finally, an overall risk of bias judgement for each study was achieved.

\section{RESULTS}

Our search strategy resulted in 3285 articles. After selection, according to the inclusion/exclusion criteria (Table 2), 46 studies were gathered and read in full-text. Finally, 14 studies were retrieved for the final analysis. The remaining 32 articles were excluded, mainly, because there were no untreated controls or the controls were not skeletal Class III patients, the treatment was combined with extractions or surgery and their objective was out of the scope of interest of the present study. Table 3 summarizes the data of the 14 included studies.

Clinical heterogeneity among studies (different outcome assessment, variable age of patients and different follow-up duration), and the high risk of bias in general precluded the quantitative synthesis of results in a meta-analysis.

\section{Skeletal Effects}

The majority of the studies showed a general improvement of skeletal Class III malocclusion, through increased ANB [17 - 22], Wits appraisal [17, 22] and decreased SNB [17 - 22], SNPg [23]. Moreover, the anterior facial height $[17,18,22,24]$, the mandibular plane angle (SN-MP) [18 - 20, 22] and the FMA [23] were significantly increased, whereas the gonial angle $[20,23,25,26]$ was significantly decreased, indicating a tendency towards a backward and downward rotation of the mandible induced by the chin-cup. Furthermore, restraint of the mandibular length was pointed out in five studies [23, 25 - 28] by significant decreases in mandibular body length [23, 27], total mandibular length [23, 26 - 28] and anteroposterior compression of the distance between the condyle and the coronoid process [25]. Significant reduction of the ramus height was also noted [22, 23, 25, 27]. With regard to the skeletal changes in the cranial base and the midface, two studies $[8,27]$ reported significant closure of the cranial flexure angle (N-S-Ba), indicating inhibition of the downward vertical growth of the midface [8] and less downward mandibular displacement relative to the cranial base [27]. 
Table 3. Data extraction.

\begin{tabular}{|c|c|c|c|c|c|c|c|c|c|}
\hline $\begin{array}{l}\text { a Article- } \\
\text { Authors- } \\
\text { Y.o.p }\end{array}$ & $\begin{array}{l}\text { Study } \\
\text { design }\end{array}$ & $\begin{array}{l}\text { Participants } \\
\text { (number-age- } \\
\text { gender) }\end{array}$ & $\begin{array}{l}\text { Interven- } \\
\text { tion }\end{array}$ & $\begin{array}{l}\text { Treatment's } \\
\text { duration }\end{array}$ & $\begin{array}{l}\text { Observational } \\
\text { period }\end{array}$ & Outcomes & $\begin{array}{l}\text { Method of } \\
\text { Outcome } \\
\text { Assessment }\end{array}$ & Results & Conclusions \\
\hline $\begin{array}{l}\text { Ritucci-Nanda } \\
{[8], 1986}\end{array}$ & $\begin{array}{l}\text { retrospec- } \\
\text { tive }\end{array}$ & $\begin{array}{l}10 \mathrm{~F} \text { treated; } \\
7 \mathrm{~F} \text { untreated } \\
\text { (age not re- } \\
\text { ported) }\end{array}$ & $\begin{array}{l}10 \mathrm{CC} ; 7 \\
\text { untreated }\end{array}$ & Not reported & $\begin{array}{l}\text { From age of } \\
5 y \text { until the } \\
\text { beginning of } \\
\text { pubertal } \\
\text { growth spurt. }\end{array}$ & $\begin{array}{l}\text { Effects on } \\
\text { growth and } \\
\text { development } \\
\text { of the cranial } \\
\text { base and } \\
\text { midface } \\
\text { produced by } \\
\text { the CC. }\end{array}$ & $\begin{array}{l}\text { Lateral cepha- } \\
\text { lometric radio- } \\
\text { graphs } \\
\text { (semiannually } \\
\text { for treated } \\
\text { patients; } \\
\text { annually for } \\
\text { controls) and } \\
\text { menarche data } \\
\text { (to assess the } \\
\text { skeletal matur- } \\
\text { ity stage). }\end{array}$ & $\begin{array}{l}\text { Significantly decreased } \\
\text { N-S-Ba angle, imposed } \\
\text { downward vertical } \\
\text { growth of the midface } \\
\text { and Mx incisors' erup- } \\
\text { tion rate. More horizontal } \\
\text { displacement of Mx 1st } \\
\text { molars. }\end{array}$ & $\begin{array}{l}\text { Closure of cranial flexure } \\
\text { angle, inhibition of the } \\
\text { downward vertical } \\
\text { growth of the midface } \\
\text { (posteriorly more evi- } \\
\text { dent). No effect on } \\
\text { anteroposterior dimen- } \\
\text { sion. Increased mesial Mx } \\
\text { molars' movement. No } \\
\text { soft-tissue changes } \\
\text { reported. }\end{array}$ \\
\hline $\begin{array}{l}\text { Alacrón et al. } \\
\text { [25], } 2011\end{array}$ & $\begin{array}{l}\text { retrospec- } \\
\text { tive }\end{array}$ & \begin{tabular}{|l|}
$50(25 \mathrm{M}, 25 \mathrm{~F})$ \\
treated, $(8.5 \pm$ \\
$0.5 \mathrm{y}) ;$ \\
$40(20 \mathrm{M}, 20 \mathrm{~F})$ \\
untreated $(8.6 \pm$ \\
$0.4 \mathrm{y})$
\end{tabular} & $\begin{array}{l}50 \mathrm{CC} ; 40 \\
\text { untreated }\end{array}$ & $36 \mathrm{~m}$ & $\begin{array}{l}\text { Until the end } \\
\text { of the treat- } \\
\text { ment. }\end{array}$ & $\begin{array}{l}\text { Mandibular } \\
\text { shape } \\
\text { changes in } \\
\text { prognathic } \\
\text { children } \\
\text { treated with } \\
\text { CC. }\end{array}$ & $\begin{array}{l}\text { Lateral cepha- } \\
\text { lometric radio- } \\
\text { graphs }+ \\
\text { geometric } \\
\text { morphometric } \\
\text { analysis. }\end{array}$ & $\begin{array}{l}\text { More rectangular corpus- } \\
\text { ramus relationship, } \\
\text { anteroposterior compres- } \\
\text { sion of the distance } \\
\text { between the condyle and } \\
\text { the coronoid process- } \\
\text { relative vertical posterior } \\
\text { ramus and gonial area } \\
\text { compression, decreased } \\
\text { gonial angle, increased } \\
\text { symphysis height and } \\
\text { narrowing. }\end{array}$ & $\begin{array}{l}\text { Wide modification of the } \\
\text { mandibular shape (more } \\
\text { rectangular Mn configu- } \\
\text { ration, forward condyle } \\
\text { orientation, gonial area } \\
\text { compression and sym- } \\
\text { physis narrowing. }\end{array}$ \\
\hline $\begin{array}{l}\text { Arman et al. } \\
{[17], 2004}\end{array}$ & $\begin{array}{l}\text { retrospec- } \\
\text { tive }\end{array}$ & $\begin{array}{l}\text { group } 1: 31 \\
(9 \mathrm{M} ; 22 \mathrm{~F}), 11.0 \\
\pm 0.24 \mathrm{y} ; \\
\text { group } 2: 14 \\
(8 \mathrm{M} ; 6 \mathrm{~F}), 11.1 \pm \\
0.49 \mathrm{y}, \\
\text { group } 3: 14 \\
(3 \mathrm{M} ; 11 \mathrm{~F}), 11.6 \\
\pm 0.61 \mathrm{y} \text { and } \\
20 \text { untreated } \\
\text { controls (gender } \\
\text { not reported), } \\
10.5 \pm 0.24 \mathrm{y} .\end{array}$ & $\begin{array}{l}\text { group 1: CC, } \\
\text { group 2: } \\
\text { CC+OBP, } \\
\text { group 3: } \\
\text { RHG; 20 } \\
\text { controls. }\end{array}$ & \begin{tabular}{|l} 
group 1: 1.0 \\
$\pm 0.15 \mathrm{y}$ \\
group 2: 1.2 \\
$\pm 0.15 \mathrm{y}$ \\
group 3: 0.9 \\
$\pm 0.09 \mathrm{y}$
\end{tabular} & $\begin{array}{l}\text { Until the end } \\
\text { of treatment } \\
\text { for the treated } \\
\text { groups; } 1.0 \pm \\
0.09 \text { y for } \\
\text { controls. }\end{array}$ & $\begin{array}{l}\text { Skeletal, } \\
\text { dentoalveolar } \\
\text { and soft- } \\
\text { tissue } \\
\text { changes of } \\
\text { CC, } \\
\text { CC+OBP, } \\
\text { RHG. Com- } \\
\text { parison of the } \\
\text { treated } \\
\text { groups with } \\
\text { untreated } \\
\text { controls and } \\
\text { with each } \\
\text { other. }\end{array}$ & $\begin{array}{l}\text { Lateral cepha- } \\
\text { lometric and } \\
\text { hand-wrist } \\
\text { radiographs. }\end{array}$ & 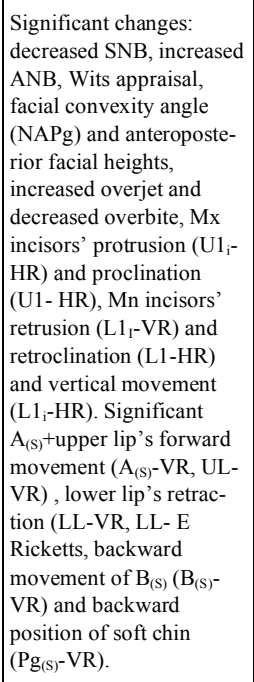 & $\begin{array}{l}\text { Significant dentoskeletal } \\
\text { improvements of skeletal } \\
\text { Class III growing pa- } \\
\text { tients. More evident soft- } \\
\text { tissue changes in the CC } \\
\text { group. Long-term evalua- } \\
\text { tion of stability is re- } \\
\text { quired. }\end{array}$ \\
\hline $\begin{array}{l}\text { Wendell } \text { et al. } \\
\text { [27], } 1985 \text {. }\end{array}$ & $\begin{array}{l}\text { retrospec- } \\
\text { tive }\end{array}$ & $\begin{array}{l}10 \mathrm{~F} \text { (age range: } \\
5 \mathrm{y} 4 \mathrm{~m}-15 \mathrm{y} \\
6 \mathrm{~m} ; 7 \mathrm{~F}(\text { age } \\
\text { range: } 6 \mathrm{y}-15 \mathrm{y} .\end{array}$ & $\begin{array}{l}10 \mathrm{CC} ; 7 \\
\text { untreated. }\end{array}$ & \begin{tabular}{|l|} 
mean time: \\
$3 y \quad 1 \mathrm{~m}$ (until \\
the correc- \\
tion of Class \\
III Maloc- \\
clusion).
\end{tabular} & $\begin{array}{l}\text { Variable for } \\
\text { treated pa- } \\
\text { tients (not } \\
\text { specified). 6y } \\
2 \mathrm{~m} \text { for the } \\
\text { controls. }\end{array}$ & $\begin{array}{l}\text { Effects of CC } \\
\text { therapy on } \\
\text { mandibular } \\
\text { growth and } \\
\text { dentition } \\
\text { studied in } \\
\text { young } \\
\text { Japanese } \\
\text { females. }\end{array}$ & $\begin{array}{l}\text { Lateral cepha- } \\
\text { lometric radio- } \\
\text { graphs (semi- } \\
\text { annually for the } \\
\text { treated patients, } \\
\text { annually for the } \\
\text { controls. }\end{array}$ & $\begin{array}{l}60-68 \% \text { significant } \\
\text { reduction of the ramal } \\
\text { length (Ar-Go), body } \\
\text { length (Go-Pg), and total } \\
\text { Mn length (Ar-Pg). } \\
\text { Continued reduction after } \\
\text { the end of active treat- } \\
\text { ment }(55-61 \%) \text {. Signifi- } \\
\text { cant closure of the N-S- } \\
\text { Ba angle and significant } \\
\text { decreases in anterior } \\
\text { facial height }(\mathrm{N}-\mathrm{Me}) \\
\text { during treatment. } 50 \% \\
\text { further sign. anterior } \\
\text { displacement of the } 1 \text { st } \\
\text { molars }\left(\mathrm{M} 6_{\mathrm{x}} \text { ) during and }\right. \\
90 \% \text { after the active } \\
\text { treatment. }\end{array}$ & $\begin{array}{l}\text { Significant reduction of } \\
\text { the absolute Mn length } \\
\text { during and after the end } \\
\text { of the active treatment. } \\
\text { Less downward Mn } \\
\text { displacement relative to } \\
\text { the cranial base. Signifi- } \\
\text { cant dental changes } \\
\text { declaring a favourable } \\
\text { migratory dental dis- } \\
\text { placement into Class I } \\
\text { occlusion. }\end{array}$ \\
\hline
\end{tabular}




\begin{tabular}{|c|c|c|c|c|c|c|c|c|c|}
\hline $\begin{array}{l}\text { Alacrón et al. } \\
{[28], 2015}\end{array}$ & $\begin{array}{l}\text { retrospec- } \\
\text { tive }\end{array}$ & $\begin{array}{l}42(21 \mathrm{M}, 21 \mathrm{~F}) \\
8.5 \pm 0.5 \mathrm{y} \\
25(12 \mathrm{M}, 13 \mathrm{~F}) \\
8.5 \pm 0.5 \mathrm{y}\end{array}$ & $\begin{array}{l}42 \mathrm{CC} ; 25 \\
\text { untreated. }\end{array}$ & $36 \pm 6 \mathrm{~m}$ & $\begin{array}{l}\text { Until the age } \\
\text { of } 11 \pm 0.6 \text { y } \\
\text { on average for } \\
\text { the treated } \\
\text { patients; Until } \\
\text { the age of } 11 \\
\pm 0.5 \text { y on } \\
\text { average for } \\
\text { controls. }\end{array}$ & \begin{tabular}{|l|} 
Soft-tissue \\
changes in \\
association to \\
any skeletal \\
and dentoal- \\
veolar \\
changes \\
induced by \\
CC.
\end{tabular} & $\begin{array}{l}\text { Lateral cepha- } \\
\text { lometric radio- } \\
\text { graphs. }\end{array}$ & $\begin{array}{l}\text { Significant changes: } \\
\text { inhibition of the sagittal } \\
\text { growth of the mandible } \\
\text { and the Mn incisors' } \\
\text { alveolus (B-GD, Pg-GD, } \\
\text { Id-GD), inhibition of the } \\
\text { total Mn length (Co-Pg), } \\
\text { decreased facial convex- } \\
\text { ity angle, lower lip's } \\
\text { inclination (Linf-E } \\
\text { Ricketts), upper lip } \\
\text { thickness, upper lip } \\
\text { protrusion (Lsup-E } \\
\text { Ricketts). Similar correla- } \\
\text { tions of changes both in } \\
\text { the hard+soft tissues apart } \\
\text { from that one between the } \\
\text { Pg retrusion and the } \\
\text { reduction in the facial } \\
\text { convexity angle. }\end{array}$ & $\begin{array}{l}\text { Short-term soft facial } \\
\text { profile improvement by } \\
\text { favourable soft-tissue } \\
\text { alterations following the } \\
\text { underlying skeletal and } \\
\text { dentoalveolar changes } \\
\text { except for a significant } \\
\text { correlation of Pogonion } \\
\text { retrusion and reduction in } \\
\text { the facial convexity } \\
\text { angle. }\end{array}$ \\
\hline $\begin{array}{l}\text { Tuncer } \text { et al. } \\
{[18], 2009}\end{array}$ & $\begin{array}{l}\text { retrospec- } \\
\text { tive }\end{array}$ & $\begin{array}{l}20(10 \mathrm{M}, 10 \mathrm{~F}) \\
10.31 \pm 1.15 \mathrm{y} \\
18(10 \mathrm{M}, 8 \mathrm{~F}) \\
9.89 \pm 1.55 \mathrm{y}\end{array}$ & \begin{tabular}{|l|}
$20 \mathrm{CC}+$ \\
$\mathrm{OBP} ;$ \\
18 untreated
\end{tabular} & $\begin{array}{l}9.78 \pm 0.93 \\
\text { y. }\end{array}$ & \begin{tabular}{|l|} 
Until the end \\
of the treat- \\
ment for the \\
treated pa- \\
tients; $11.14 \pm$ \\
0.24 y for the \\
untreated \\
controls.
\end{tabular} & $\begin{array}{l}\text { Examination } \\
\text { of the sagittal } \\
\text { pharyngeal } \\
\text { dimensions } \\
\text { after CCther- } \\
\text { apy. }\end{array}$ & $\begin{array}{l}\text { Lateral cepha- } \\
\text { lometric and } \\
\text { hand-wrist } \\
\text { radiographs. }\end{array}$ & $\begin{array}{l}\text { Significant changes: } \\
\text { decreased SNB and } \\
\text { increased Sn-GoGn } \\
\text { angles, increased total (N- } \\
\text { Me) and upper heights. } \\
\text { increased nasopharyngeal } \\
\text { area and downward } \\
\text { movement of the hyoid } \\
\text { bone (H-SN). }\end{array}$ & $\begin{array}{l}\text { Short-term downward and } \\
\text { backward rotation of the } \\
\text { mandible, increased } \\
\text { vertical height, increased } \\
\text { nasopharyngeal airway } \\
\text { area. }\end{array}$ \\
\hline $\begin{array}{l}\text { Gökalp and } \\
\text { Kurt [29], } \\
2005 .\end{array}$ & $\begin{array}{l}\text { prospec- } \\
\text { tive }\end{array}$ & $\begin{array}{l}13(3 \mathrm{M}, 10 \mathrm{~F}), \\
9.06 \mathrm{y} \\
7(1 \mathrm{M}, 6 \mathrm{~F}) \\
8.90 \mathrm{y} .\end{array}$ & $\begin{array}{l}13 \mathrm{CC} \\
7 \text { untreated }\end{array}$ & $1 \mathrm{y} 7 \mathrm{~m}$. & $\begin{array}{l}\text { Until the end } \\
\text { of the treat- } \\
\text { ment. }\end{array}$ & \begin{tabular}{|l|} 
Investigation \\
of skeletal \\
Class III \\
improvement \\
after CC \\
therapy.
\end{tabular} & $\begin{array}{l}\text { Lateral cepha- } \\
\text { lometric radio- } \\
\text { graphs and } \\
\text { Magnetic } \\
\text { resonance } \\
\text { imaging. }\end{array}$ & $\begin{array}{l}\text { Significantly increased } \\
\text { Mn body length and } \\
\text { overjet. }\end{array}$ & $\begin{array}{l}\text { CC alters the condylar } \\
\text { growth pattern by produc- } \\
\text { ing morphological } \\
\text { changes of the TMJ } \\
\text { components and remodel- } \\
\text { ling of the mandible } \\
\text { towards an improved } \\
\text { skeletal Class III maloc- } \\
\text { clusion. }\end{array}$ \\
\hline $\begin{array}{l}\text { Sakamoto } \\
\text { et al. }[23] \text {, } \\
1984 .\end{array}$ & $\begin{array}{l}\text { retrospec- } \\
\text { tive }\end{array}$ & $\begin{array}{l}26 \mathrm{~F}, \text { (age range: } \\
6-9 \text { y). } \\
1 \mathrm{~F} \text { from the } \\
\text { treated group } \\
\text { was cross- } \\
\text { sectionally } \\
\text { contrasted to } \\
423 \mathrm{~F} \text { (age } \\
\text { range: } 3-30 \mathrm{y}) \text { to } \\
\text { illustrate the } \\
\text { reported skeletal } \\
\text { changes induced } \\
\text { by CC. }\end{array}$ & \begin{tabular}{|l|}
26 CC \\
(+additional \\
double \\
spring \\
lingual arch \\
in some \\
cases). \\
\\
423 un- \\
treated.
\end{tabular} & $\begin{array}{l}\text { Not re- } \\
\text { ported. }\end{array}$ & $\begin{array}{l}\text { More than } 2 \mathrm{y} \\
\text { after the end } \\
\text { of CC therapy. }\end{array}$ & \begin{tabular}{|l|} 
Skeletal \\
changes and \\
post- \\
treatment \\
stability after \\
CC therapy.
\end{tabular} & $\begin{array}{l}\text { Lateral cepha- } \\
\text { lometric radio- } \\
\text { graphs. }\end{array}$ & $\begin{array}{l}\text { During treatment: de- } \\
\text { creased SNPg, increased } \\
\text { ANB, FMA angles, } \\
\text { restraint of growth (Mn } \\
\text { body, ramus, Mn length, } \\
\text { facial length), decreased } \\
\text { gonial angle. 1y after the } \\
\text { removal of CC: Forward } \\
\text { Mn displacement (in- } \\
\text { creased SNPg, decreased } \\
\text { ANPg angles). } 2 \text { y after } \\
\text { the removal of CC: no } \\
\text { changes not maintained. }\end{array}$ & $\begin{array}{l}\text { Restraint of growth was } \\
\text { noted during CC therapy, } \\
\text { but relapsed after the end } \\
\text { of the treatment. No } \\
\text { obvious changes in the } \\
\text { cranium and the maxilla. } \\
\text { Similar growth in Mn } \\
\text { increments before and } \\
\text { after the removal of CC. }\end{array}$ \\
\hline $\begin{array}{l}\text { Deguchi and } \\
\text { McNamara } \\
{[26], 1999 .}\end{array}$ & $\begin{array}{l}\text { retrospec- } \\
\text { tive }\end{array}$ & $\begin{array}{l}22 \mathrm{~F}, 9 \mathrm{y} 4 \mathrm{~m} \\
20 \mathrm{~F}, 9 \mathrm{y} 7 \mathrm{~m}\end{array}$ & \begin{tabular}{|l|}
$22 \mathrm{CC}(+$ \\
additional \\
lingual arch \\
to flare the \\
upper \\
incisors); 20 \\
untreated.
\end{tabular} & 1y $9 \mathrm{~m}$. & $\begin{array}{l}28 \pm 7.9 \mathrm{~m} \text { for } \\
\text { the treated } \\
\text { patients; } 30 \pm \\
12 \mathrm{~m} \text { for the } \\
\text { controls. }\end{array}$ & $\begin{array}{l}\text { Investigation } \\
\text { of the ortho- } \\
\text { pedic effect } \\
\text { of CC in the } \\
\text { posterior } \\
\text { displacement } \\
\text { of the mandi- } \\
\text { ble and the } \\
\text { glenoid fossa. }\end{array}$ & $\begin{array}{l}\text { Lateral cepha- } \\
\text { lometric and } \\
\text { hand-wrist } \\
\text { radiographs. }\end{array}$ & $\begin{array}{l}\text { Significantly decreased } \\
\text { gonial angle, less incre- } \\
\text { mental increase in Mn } \\
\text { length (Gn-Cd), posterior } \\
\text { movement of points B } \\
\text { and } \mathrm{Pg} \text {, not increased } \\
\text { anterior facial height. }\end{array}$ & $\begin{array}{l}\text { Reduction in Mn growth } \\
\text { increments. }\end{array}$ \\
\hline $\begin{array}{l}\text { Akin et al. } \\
{[19], 2015 .}\end{array}$ & $\begin{array}{l}\text { retrospec- } \\
\text { tive }\end{array}$ & $\begin{array}{l}25(9 \mathrm{M}, 16 \mathrm{~F}) \\
9.8 \pm 1.6 \mathrm{y} \\
25(10 \mathrm{M}, 15 \mathrm{~F}) \\
10.3 \pm 1.5 \mathrm{y} \\
17(8 \mathrm{M}, 9 \mathrm{~F}) \\
10.1 \pm 1.3 \mathrm{y}\end{array}$ & \begin{tabular}{|l|}
$25 \mathrm{CC}+$ \\
OBP (flat \\
surface Essix \\
plate); \\
25 facemask; \\
17 untreated.
\end{tabular} & $\begin{array}{l}\text { Not re- } \\
\text { ported. }\end{array}$ & $\begin{array}{l}\text { Until the end } \\
\text { of the treat- } \\
\text { ment for the } \\
\text { treated pa- } \\
\text { tients; } 6 \mathrm{~m} \text { for } \\
\text { the untreated. }\end{array}$ & \begin{tabular}{|l|} 
Orofacial \\
airway \\
dimensional \\
effects of \\
facemask or \\
CC compared \\
to untreated \\
controls.
\end{tabular} & $\begin{array}{l}\text { Lateral cepha- } \\
\text { lometric and } \\
\text { hand-wrist } \\
\text { radiographs. }\end{array}$ & $\begin{array}{l}\text { Significant changes: } \\
\text { decreased SNB, increased } \\
\text { ANB and Sn-GoGn } \\
\text { angles, forward move- } \\
\text { ment and proclination of } \\
\text { Mx incisors (increased } \\
\text { U1-NA), backward } \\
\text { movement and retroclina- } \\
\text { tion of Mn incisors (L1- }\end{array}$ & $\begin{array}{l}\text { CC therapy is found to } \\
\text { induce clockwise Mn } \\
\text { rotation. Although it does } \\
\text { not significantly affect } \\
\text { the pharyngeal airway } \\
\text { dimensions, it moves the } \\
\text { hyoid bone to a more } \\
\text { inferior position in } \\
\text { comparison with both the }\end{array}$ \\
\hline
\end{tabular}




\begin{tabular}{|c|c|c|c|c|c|c|c|c|c|}
\hline & & & & & & & & $\begin{array}{l}\text { NB), increased UL-E } \\
\text { Ricketts, indicating } \\
\text { protrusion of the upper } \\
\text { lip. Changes in the } \\
\text { perpendicular distance } \\
\text { from hyoid }(\mathrm{H}) \text { to the C3- } \\
\text { Me line compared to } \\
\text { controls. }\end{array}$ & $\begin{array}{l}\text { facemask and the un- } \\
\text { treated patients groups. }\end{array}$ \\
\hline $\begin{array}{l}\text { Lin et al. [20], } \\
2007 .\end{array}$ & $\begin{array}{l}\text { retrospec- } \\
\text { tive }\end{array}$ & $\begin{array}{l}20(10 \mathrm{M}, 10 \mathrm{~F}) \\
9 \mathrm{y} 11 \mathrm{~m} ; \\
20(10 \mathrm{M}, 10 \mathrm{~F}) \\
9 \mathrm{y} 6 \mathrm{~m} .\end{array}$ & $\begin{array}{l}20 \text { OMA; } \\
20 \text { untreated. }\end{array}$ & $1 \mathrm{y} 4 \mathrm{~m}$. & $\begin{array}{l}\text { Until the end } \\
\text { of the treat- } \\
\text { ment for the } \\
\text { treated pa- } \\
\text { tients; } 1 \mathrm{y} 5 \mathrm{~m} \\
\text { for the un- } \\
\text { treated. }\end{array}$ & \begin{tabular}{|l|} 
Skeletal and \\
dental \\
changes \\
induced by \\
an orthopedic \\
OMA.
\end{tabular} & $\begin{array}{l}\text { Lateral cepha- } \\
\text { lometric radio- } \\
\text { graphs. }\end{array}$ & $\begin{array}{l}\text { Significant changes: } \\
\text { Forward movement of } \\
\text { point A, increase in Mx } \\
\text { length, increased SNA, } \\
\text { horizontal change of } \\
\text { point B, increase in the } \\
\text { Mn plane (Sn-MP) and } \\
\text { the ramus plane angles, } \\
\text { decreased SNB and } \\
\text { gonial angles, labial } \\
\text { tipping of Mx incisors, } \\
\text { horizontal change in the } \\
\text { Mn incisors' tip, in- } \\
\text { creased overjet. }\end{array}$ & $\begin{array}{l}\text { OMA induces short-term } \\
\text { favourable skeletal } \\
\text { (forward growth of the } \\
\text { Mx complex, backward } \\
\text { and downward rotation of } \\
\text { the Mn, restraint in } \\
\text { forward Mn advance- } \\
\text { ment) and dentoalveolar } \\
\text { effects (labial tipping of } \\
\text { Mx incisors). }\end{array}$ \\
\hline $\begin{array}{l}\text { Barrett et al. } \\
{[21], 2010 .}\end{array}$ & $\begin{array}{l}\text { retrospec- } \\
\text { tive }\end{array}$ & \begin{tabular}{|l|}
$26(11 \mathrm{M}, 15 \mathrm{~F})$, \\
8.5 y treated \\
patients divided \\
in: group $1: 12$ \\
patients; \\
group $2: 14$ \\
patients; \\
$20(6 \mathrm{M}, 14 \mathrm{~F})$, \\
$7.3 y$ untreated.
\end{tabular} & $\begin{array}{l}\text { group 1: } 12 \\
\text { CC + QH; } \\
\text { group 2: } 14 \\
\text { CC only; } \\
20 \text { untreated. }\end{array}$ & $\begin{array}{l}2.6 \mathrm{y} \text { for the } \\
\mathrm{CC}, 2 . .4 \mathrm{y} \\
\text { for controls. }\end{array}$ & $\begin{array}{l}\text { Until the end } \\
\text { of treatment. }\end{array}$ & $\begin{array}{l}\text { Skeletal and } \\
\text { dentoalveolar } \\
\text { changes } \\
\text { induced by } \\
\text { CC. }\end{array}$ & $\begin{array}{l}\text { Lateral cepha- } \\
\text { lometric radio- } \\
\text { graphs. }\end{array}$ & $\begin{array}{l}\text { Significant changes: a) } \\
\text { skeletal: decreased SNB, } \\
\text { increased ANB, decrease } \\
\text { in palatal plane angle } \\
\text { (FH-PP), b) dentoalveo- } \\
\text { lar: uprighting of Mn } \\
\text { incisors (decreased } \\
\text { IMPA), decreased L1-APg } \\
\text { and L1 horizontal move- } \\
\text { ment, increased overjet, c) } \\
\text { soft-tissue: decreased LL- } \\
\text { E Ricketts and increased } \\
\text { nasolabial angle. }\end{array}$ & $\begin{array}{l}\text { Limited Class III correc- } \\
\text { tion with light force CC } \\
\text { (fewer than } 50 \% \text { of the } \\
\text { patients) mostly by } \\
\text { dentoalveolar (uprighting } \\
\text { of Mn incisors) rather } \\
\text { than orthopedic changes. }\end{array}$ \\
\hline $\begin{array}{l}\text { Abu Alhaija } \\
\text { and } \\
\text { Richardson } \\
\text { [24], 1999. }\end{array}$ & $\begin{array}{l}\text { retrospec- } \\
\text { tive }\end{array}$ & \begin{tabular}{|l|}
$23(14 \mathrm{M}, 9 \mathrm{~F})$ \\
$8.11 \pm 0.96 \mathrm{y} ;$ \\
23 matched (age \\
not reported).
\end{tabular} & $\begin{array}{l}23 \\
\mathrm{CC}+\mathrm{URA} ; \\
23 \text { un- } \\
\text { treated. }\end{array}$ & $\begin{array}{l}3.01 \pm 1.61 \\
\mathrm{y}\end{array}$ & $\begin{array}{l}3.34 \pm 1.80 \mathrm{y} \\
\text { after the end } \\
\text { of treatment; } \\
4.12 \pm 1.86 \mathrm{y} \\
\text { for the un- } \\
\text { treated. }\end{array}$ & \begin{tabular}{|l|} 
Short-and \\
long-term \\
effects of CC \\
therapy \\
combined \\
with an URA \\
in Class III \\
patients.
\end{tabular} & $\begin{array}{l}\text { Lateral cepha- } \\
\text { lometric radio- } \\
\text { graphs. }\end{array}$ & $\begin{array}{l}\text { Significant changes: a) at } \\
\text { the end of the active } \\
\text { treatment: increased Mn } \\
\text { length and facial height, } \\
\text { retroclination of lower } \\
\text { and proclination of upper } \\
\text { incisors, increased } \\
\text { overjet, nasolabial angle } \\
\text { and improvement of soft- } \\
\text { tissue profile, b) post- } \\
\text { treatment: further Mn } \\
\text { growth (increased SNB, } \\
\text { Wits appraisal), increased } \\
\text { facial height, maintained } \\
\text { overjet, forward move- } \\
\text { ment of the upper- and } \\
\text { the lower lip, forward } \\
\text { inferior movement of the } \\
\text { chin. }\end{array}$ & $\begin{array}{l}\text { Long-term proclination of } \\
\text { the upper incisors, } \\
\text { retroclination of the lower } \\
\text { incisors, downward } \\
\text { redirection of Mn growth } \\
\text { and soft-tissue profile } \\
\text { improvement. }\end{array}$ \\
\hline $\begin{array}{l}\text { Abdelanby } \\
\text { and Nassar } \\
\text { [22], 2010. }\end{array}$ & $\begin{array}{l}\text { retrospec- } \\
\text { tive }\end{array}$ & $\begin{array}{l}\text { group 1: } 20 \\
(10 \mathrm{M}, 10 \mathrm{~F}) \\
9.6 \mathrm{y} ; \\
\text { group 2: } 20 \\
(9 \mathrm{M}, 11 \mathrm{~F}) \\
10.1 \mathrm{y} ; \\
\text { group 3: } 10 \\
(5 \mathrm{M}, 5 \mathrm{~F}), 9.2 \mathrm{y} .\end{array}$ & $\begin{array}{l}20 \mathrm{CC}+\mathrm{OBP} \\
(600 \mathrm{gr} \text { per } \\
\text { side }) ; \\
20 \mathrm{CC}+\mathrm{OBP} \\
(300 \mathrm{gr} \text { per } \\
\text { side); } \\
10 \text { untreated. }\end{array}$ & $1 \mathrm{y}$. & $\begin{array}{l}1 \mathrm{y} \text { for the } \\
\text { untreated } \\
\text { patients. }\end{array}$ & \begin{tabular}{|l|} 
Skeletal and \\
dental effects \\
of CC using 2 \\
force magni- \\
tude (300,600 \\
gr per side) in \\
Class III \\
growing \\
patients.
\end{tabular} & $\begin{array}{l}\text { Lateral cepha- } \\
\text { lometric and } \\
\text { hand-wrist } \\
\text { radiographs. }\end{array}$ & $\begin{array}{l}\text { Significantly decreased } \\
\text { SNB, Mn ramus height } \\
\text { (Ar-Go), increased ANB, } \\
\text { Wits appraisal, anterior, } \\
\text { facial height (N-Me) Mn } \\
\text { plane angle (SN-MP) and } \\
\text { retroclination of Mn } \\
\text { incisors. }\end{array}$ & $\begin{array}{l}\text { Limited skeletal changes } \\
\text { irrespective of utilization } \\
\text { of force magnitude per } \\
\text { side except for the } \\
\text { reduction of the ramus } \\
\text { height. }\end{array}$ \\
\hline
\end{tabular}

${ }^{a}$ The cited references of the articles in the first column of the table correspond to the numbered references in the text.

Y.o.P: indicates year of publication, M: males, F: females, y: years, m: months, Mx: maxillary, Mn: mandibular, CC: chin-cup, OBP: occlusal bite plate, RHG: reversed headgear, OMA: occipitomental anchorage appliance of maxillary protraction combined with chin-cup traction, QH: quad-helix, URA: upper removable appliance, U1i: upper incisor's tip, L1I: OMA: occipitomental anchorage appliance of maxillary protraction combined with chin-cup t
lower incisor's tip, $\mathrm{A}(\mathrm{S}), \mathrm{B}(\mathrm{S}), \operatorname{Pg}(\mathrm{S})$ : soft tissue points A,B,Pg respectively, Id: infradentale. 


\section{Dento-Alveolar Effects}

The main dento-alveolar changes produced by the chin-cup were the achievement of a significant overjet [17, 20 22, 24, 29] and retroclination of the lower incisors [17, 19, 21, 22, 24]. More precisely, Ritucci and Nanda [8] declared that transition in overjet occurred with a marked degree of flaring of the maxillary incisors, followed by a variable amount of uprighting, based on lateral cephalograms. Overjet correction was, also, reported byAlacrón et al. [25], mainly achieved by mandibular incisor retroclination. Moreover, Barrett et al. [21] noted the uprighting of the lower incisors, indicated by the decreased IMPA, as the most significant dental change between the chin-cup and the control groups. Significant proclination of the upper incisors $[8,17,19,20,24]$ was also pointed out. However, the aforementioned results, especially those regarding the proclined upper incisors, should be carefully interpreted in order to clarify whether they constitute net effects of the chin-cup alone or the additional appliances that were used and were co-interventions.

Changes regarding overbite varied, depending on the appliance that was used. More specifically, Arman et al. [17] noted a significant decrease in overbite in all the treated groups (chin-cups only, chin-cups with removable bite plate, reverse headgear with rapid maxillary expansion devices).

Regarding the molar relationship after the active treatment, Ritucci and Nanda [8] declared that chin-cups accelerate the mesial movement of maxillary molars, without any effect on their eruption rate, while Wendell et al. [27] manifested that the initial Class III occlusion was corrected to Class I relationship in all of the patients.

\section{Soft-Tissue Effects}

The effects of chin-cup therapy on the soft tissues were reported in five studies $[17,19,21,24,28]$. Significant forward movement of the upper lip was declared in four studies [17, 19, 24, 28] with a concomitant forward movement of the soft-tissue point A [17], while the movement of the lower lip presented differing results. Arman et al. [17], Alacrón et al. [28] and Barrett et al. [21] stated a decreased distance of the lower lip to E plane (LL-E Ricketts line [17, 21, 28]) and lower lip's retraction (LL-VR [17]) with a concomitant backward movement of the soft-tissue point B [17] and the soft chin $\left(\operatorname{Pg}_{(s)}[17,28]\right)$. However, Abu Alhaija and Richardson [24] showed significant forward movement of the lower lip [24]. A general soft-tissue facial profile improvement was attributed to the chin-cup by Alacrón et al. [28], who demonstrated similar correlations between the changes in the hard and in the soft tissues, especially the one between a significant reduction of the facial convexity angle and a significant pogonion retrusion in the chin-cup group.

\section{Stability}

Two studies $[23,24]$ reported information concerning the stability of treatment outcomes, using cephalometric xrays at a post-treatment observation. Abu Alhaija and Richardson et al. [24], following a one-year post-treatment cephalometric observation, reported a significant increase in mandibular length, which was in accordance with Sakamoto et al. [23], whose study found a forward displacement of the mandible in one-year post-treatment observation and total relapse in the original mandibular growth pattern after two years. Both studies [23, 24] showed a significant increase in the anterior face height.

As for the dental effects, the significantly increased overjet achieved by chin-cups was maintained one year after the end of the treatment [24].

Although stability in the soft-tissue profile was evident at the post-treatment observation, the upper, the lower lip and the chin continued to grow forward following the skeletal pattern [24].

\section{Quality Analysis}

The overall judgement for the risk of bias was found serious for all the retrieved studies, (Table 4). All had a serious risk of bias concerning the selection of participants into the study (selection bias). Based on the ACROBAT-NRSI [13], all the studies were found to have some important problems in the corresponding domains, indicating cautious interpretation of the reported results.

\section{DISCUSSION}

In this systematic review, our primary goal was to search the existing literature for randomized and control clinical trials regarding the short- and long-term effects of chin-cup therapy on hard and soft tissues of growing patients. These had to include untreated patients as controls. 
Table 4. Risk of bias assessment (ACROBAT-NRSI).

\begin{tabular}{|c|c|c|c|c|c|c|c|c|}
\hline $\begin{array}{l}{ }^{\text {a }} \text { Authors- } \\
\text { Article- } \\
\text { Y.o.P. }\end{array}$ & $\begin{array}{l}\text { Bias due to } \\
\text { confounding }\end{array}$ & $\begin{array}{l}\text { Bias in selection } \\
\text { of participants } \\
\text { into the study }\end{array}$ & $\begin{array}{l}\text { Bias in measure- } \\
\text { ment of interven- } \\
\text { tions }\end{array}$ & $\begin{array}{l}\text { Bias due to depar- } \\
\text { tures from intended } \\
\text { interventions }\end{array}$ & \begin{tabular}{|l} 
Bias due to \\
missing data
\end{tabular} & $\begin{array}{l}\text { Bias in measure- } \\
\text { ment of outcomes }\end{array}$ & $\begin{array}{l}\text { Bias in selection of } \\
\text { the reported result }\end{array}$ & $\begin{array}{l}\text { Overall Judge- } \\
\text { ment }\end{array}$ \\
\hline $\begin{array}{l}\text { Ritucci- } \\
\text { Nanda [8], } \\
1986\end{array}$ & $\begin{array}{l}\text { Outcomes: O1, } \\
\text { O2. } \\
\text { Risk: Moderate } \\
\text { SfJ: confound- } \\
\text { ing expected } \\
\text { (pre-treatment } \\
\text { overjet), but } \\
\text { probably elimi- } \\
\text { nated since as it } \\
\text { was stated "the } \\
\text { occlusion } \\
\text { changed from } \\
\text { one with an } \\
\text { underjet to one } \\
\text { with an over- } \\
\text { jet". }\end{array}$ & $\begin{array}{l}\text { Outcomes: O1, } \\
\text { O2. } \\
\text { Risk: Serious } \\
\text { SfJ: Selection into } \\
\text { the study was } \\
\text { related to interven- } \\
\text { tion and probably } \\
\text { the outcome. }\end{array}$ & $\begin{array}{l}\text { Outcomes: O1, } \\
\text { O2. } \\
\text { Risk: Moderate } \\
\text { SfJ: Intervention } \\
\text { status is well } \\
\text { defined, but data } \\
\text { were determined } \\
\text { retrospectively in a } \\
\text { way that could } \\
\text { have been affected } \\
\text { by knowledge of } \\
\text { the outcome. }\end{array}$ & $\begin{array}{l}\text { Outcomes: O1, O2. } \\
\text { Risk: Low } \\
\text { SfJ: No bias due to } \\
\text { departures from } \\
\text { intended intervention } \\
\text { is expected. }\end{array}$ & $\begin{array}{l}\text { Outcomes: O1, } \\
\text { O2. } \\
\text { Risk: Low } \\
\text { SfJ: Data were } \\
\text { reasonably } \\
\text { complete. }\end{array}$ & $\begin{array}{l}\text { Outcomes: O1, } \\
\text { O2. } \\
\text { Risk: Serious } \\
\text { SfJ: Outcome } \\
\text { measure was } \\
\text { subjective, the } \\
\text { assessor was aware } \\
\text { of the received } \\
\text { intervention and } \\
\text { any systematic } \\
\text { error in measure- } \\
\text { ments was related } \\
\text { to intervention } \\
\text { status. }\end{array}$ & $\begin{array}{l}\text { Outcomes: O1, O2. } \\
\text { Risk: Moderate } \\
\text { SfJ: Outcome } \\
\text { measurements and } \\
\text { analysis were clearly } \\
\text { defined, internally } \\
\text { and externally } \\
\text { consistent, there was } \\
\text { no indication of } \\
\text { selection of the } \\
\text { reported analysis } \\
\text { from among multi- } \\
\text { ple analyses and no } \\
\text { indication of selec- } \\
\text { tion of the cohort or } \\
\text { subgroups for } \\
\text { analysis and report- } \\
\text { ing on the basis of } \\
\text { the results. }\end{array}$ & $\begin{array}{l}\text { Risk: Serious } \\
\text { SfJ: The study } \\
\text { has some impor- } \\
\text { tant problems, e.g: } \\
\text { serious risk of } \\
\text { selection bias } \\
\text { (selection of the } \\
\text { participants), } \\
\text { detection bias, } \\
\text { measurement bias } \\
\text { and observer bias. }\end{array}$ \\
\hline $\begin{array}{l}\text { Alacrón et al. } \\
{[25], 2011}\end{array}$ & $\begin{array}{l}\text { Outcomes: O1, } \\
\text { O2. } \\
\text { Risk: Low } \\
\text { SfJ: No con- } \\
\text { founding } \\
\text { expected. }\end{array}$ & $\begin{array}{l}\text { Outcomes: O1, } \\
\text { O2. } \\
\text { Risk: Serious } \\
\text { SfJ: Selection into } \\
\text { the study was } \\
\text { related to interven- } \\
\text { tion and probably } \\
\text { the outcome. }\end{array}$ & $\begin{array}{l}\text { Outcomes: O1, } \\
\text { O2. } \\
\text { Risk: Moderate } \\
\text { SfJ: Intervention } \\
\text { status is well } \\
\text { defined, but data } \\
\text { were obtained } \\
\text { retrospectively. }\end{array}$ & $\begin{array}{l}\text { Outcomes: O1, O2. } \\
\text { Risk: Low } \\
\text { SfJ: No bias due to } \\
\text { departures from } \\
\text { intended intervention } \\
\text { is expected. }\end{array}$ & $\begin{array}{l}\text { Outcomes: O1, } \\
\text { O2. } \\
\text { Risk: Low } \\
\text { SfJ: Data were } \\
\text { reasonably } \\
\text { complete. }\end{array}$ & $\begin{array}{l}\text { Outcomes: O1, } \\
\text { O2. } \\
\text { Risk: Low SfJ: } \\
\text { Comparable } \\
\text { outcome assess- } \\
\text { ment methods } \\
\text { between the } 2 \\
\text { groups and blinded } \\
\text { assessor to inter- } \\
\text { vention status and } \\
\text { any systematic } \\
\text { error in measure- } \\
\text { ments unrelated to } \\
\text { intervention status. }\end{array}$ & $\begin{array}{l}\text { Outcomes: O1, O2. } \\
\text { Risk: Moderate } \\
\text { SfJ: Outcome } \\
\text { measurements and } \\
\text { analysis were } \\
\text { clearly defined, } \\
\text { internally and } \\
\text { externally consis- } \\
\text { tent, there was no } \\
\text { indication of } \\
\text { selection of the } \\
\text { reported analysis } \\
\text { from among multiple } \\
\text { analyses and no } \\
\text { indication of selec- } \\
\text { tion of the cohort or } \\
\text { subgroups for } \\
\text { analysis and report- } \\
\text { ing on the basis of } \\
\text { the results. }\end{array}$ & $\begin{array}{l}\text { Risk: Serious } \\
\text { SfJ: The study } \\
\text { has an important } \\
\text { problem, e.g: } \\
\text { serious risk of } \\
\text { selection bias } \\
\text { (selection of the } \\
\text { participants). }\end{array}$ \\
\hline $\begin{array}{l}\text { Arman et al. } \\
{[17], 2004}\end{array}$ & $\begin{array}{l}\text { Outcomes: O1, } \\
\text { O2, O3. } \\
\text { Risk: Serious } \\
\text { SfJ: Critically } \\
\text { important } \\
\text { confounders } \\
\text { (ethnicity, } \\
\text { Skeletal Class of } \\
\text { malocclusion } \\
\text { and soft-tissue } \\
\text { profile variation) } \\
\text { not measured } \\
\text { and not adjusted } \\
\text { for in the } \\
\text { analysis. }\end{array}$ & $\begin{array}{l}\text { Outcomes: O1, } \\
\text { O2, O3. } \\
\text { Risk: Serious } \\
\text { SfJ: Selection into } \\
\text { the study was } \\
\text { related to interven- } \\
\text { tion and probably } \\
\text { the outcome. }\end{array}$ & $\begin{array}{l}\text { Outcomes: O1, } \\
\text { O2, O3. } \\
\text { Risk: Serious } \\
\text { SfJ: Intervention } \\
\text { status may be well } \\
\text { defined, but data } \\
\text { were obtained } \\
\text { retrospectively and } \\
\text { determined in a } \\
\text { way that could } \\
\text { have been affected } \\
\text { by knowledge of } \\
\text { the outcome. }\end{array}$ & $\begin{array}{l}\text { Outcomes: } \mathrm{O} 1, \mathrm{O} 2, \\
\text { O3. } \\
\text { Risk: Serious } \\
\text { SfJ: Co-interventions } \\
\text { are apparent (OBP, } \\
\text { RHG) and not adjusted } \\
\text { for in the analysis. }\end{array}$ & $\begin{array}{l}\text { Outcomes: O1, } \\
\text { O2, O3. } \\
\text { Risk: Moder- } \\
\text { ate } \\
\text { SfJ: Reasons } \\
\text { for missingness } \\
\text { (for baseline } \\
\text { characteristics } \\
\text { and con- } \\
\text { founders) differ } \\
\text { minimally } \\
\text { across interven- } \\
\text { tions and } \\
\text { missing data } \\
\text { were not } \\
\text { addressed in } \\
\text { the analysis. }\end{array}$ & $\begin{array}{l}\text { Outcomes: O1, } \\
\text { O2, O3. } \\
\text { Risk:Moderate } \\
\text { SfJ:Comparable } \\
\text { outcome assess- } \\
\text { ment methods } \\
\text { between the groups } \\
\text { and outcome } \\
\text { measure only } \\
\text { minimally influ- } \\
\text { enced by knowl- } \\
\text { edge of the inter- } \\
\text { vention (blinding } \\
\text { not reported) and } \\
\text { any systematic } \\
\text { error in measure- } \\
\text { ments only mini- } \\
\text { mally related to } \\
\text { intervention status. }\end{array}$ & $\begin{array}{l}\text { Outcomes: O1, O2, } \\
\text { O3. } \\
\text { Risk: Moderate } \\
\text { SfJ: Relative low } \\
\text { risk of selective } \\
\text { reporting, because } \\
\text { all results were } \\
\text { declared for each } \\
\text { group in compari- } \\
\text { son with each other. }\end{array}$ & $\begin{array}{l}\text { Risk: Serious } \\
\text { SfJ: The study } \\
\text { has some impor- } \\
\text { tant problems, e.g: } \\
\text { serious risk of } \\
\text { selection bias } \\
\text { (residual con- } \\
\text { founding, selec- } \\
\text { tion of the partici- } \\
\text { pants) and per- } \\
\text { formance bias. }\end{array}$ \\
\hline $\begin{array}{l}\text { Wendell } \text { et al. } \\
{[27], 1985 \text {. }}\end{array}$ & $\begin{array}{l}\text { Outcomes: O1, } \\
\text { O2. } \\
\text { Risk: Serious } \\
\text { SfJ: Serious } \\
\text { residual con- } \\
\text { founding, } \\
\text { because of } \\
\text { variation in the } \\
\text { onset, duration } \\
\text { and amount of }\end{array}$ & $\begin{array}{l}\text { Outcomes: O1, } \\
\text { O2.. } \\
\text { Risk: Serious } \\
\text { SfJ: Selection into } \\
\text { the study was } \\
\text { related to interven- } \\
\text { tion and probably } \\
\text { the outcome. }\end{array}$ & $\begin{array}{l}\text { Outcomes: O1, } \\
\text { O2.. } \\
\text { Risk: Serious } \\
\text { SfJ: Intervention } \\
\text { status is not well } \\
\text { defined (not } \\
\text { explicit timing of } \\
\text { intervention), } \\
\text { retrospectively } \\
\text { obtained and }\end{array}$ & $\begin{array}{l}\text { Outcomes: O1, O2. . } \\
\text { Risk: Moderate SfJ: } \\
\text { No co-interventions, } \\
\text { no switches and } \\
\text { probably minor } \\
\text { implementation } \\
\text { fidelity. }\end{array}$ & $\begin{array}{l}\text { Outcomes: O1, } \\
\text { O2.. } \\
\text { Risk: Serious } \\
\text { SfJ: The nature } \\
\text { of the missing } \\
\text { data (on } \\
\text { baseline } \\
\text { confounders) } \\
\text { means that the } \\
\text { risk of bias }\end{array}$ & $\begin{array}{l}\text { Outcomes: O1, } \\
\text { O2.. } \\
\text { Risk: Serious } \\
\text { SfJ: Any system- } \\
\text { atic error in } \\
\text { measurements was } \\
\text { related to interven- } \\
\text { tion status and the } \\
\text { assessor was aware } \\
\text { of the received }\end{array}$ & $\begin{array}{l}\text { Outcomes: O1, O2. } \\
\text { Risk: Moderate } \\
\text { SfJ: Outcome } \\
\text { measurements and } \\
\text { analysis were } \\
\text { clearly defined, } \\
\text { internally and } \\
\text { externally consis- } \\
\text { tent, there was no }\end{array}$ & $\begin{array}{l}\text { Risk: Serious } \\
\text { SfJ: The study } \\
\text { has some impor- } \\
\text { tant problems, e.g: } \\
\text { serious risk of } \\
\text { selection bias } \\
\text { (residual con- } \\
\text { founding, selec- } \\
\text { tion of the partici- } \\
\text { pants), informa- }\end{array}$ \\
\hline
\end{tabular}




\begin{tabular}{|c|c|c|c|c|c|c|c|c|}
\hline & $\begin{array}{l}\text { the growth } \\
\text { peaks of the } \\
\text { patients, as well } \\
\text { as in the onset } \\
\text { and duration of } \\
\text { the treatment } \\
\text { time. Also the } 2 \\
\text { treatment } \\
\text { periods of } \\
\text { patient } 13 \\
\text { indicate time- } \\
\text { varying con- } \\
\text { founding. }\end{array}$ & & $\begin{array}{l}\text { likely to have been } \\
\text { influenced by } \\
\text { knowledge of the } \\
\text { received interven- } \\
\text { tion. }\end{array}$ & & $\begin{array}{l}\text { cannot be } \\
\text { removed } \\
\text { through appro- } \\
\text { priate analysis. }\end{array}$ & intervention. & $\begin{array}{l}\text { indication of } \\
\text { selection of the } \\
\text { reported analysis } \\
\text { from among } \\
\text { multiple analyses } \\
\text { and no indication of } \\
\text { selection of the } \\
\text { cohort or subgroups } \\
\text { for analysis and } \\
\text { reporting on the } \\
\text { basis of the results. }\end{array}$ & $\begin{array}{l}\text { tion bias, per- } \\
\text { formance bias, } \\
\text { detection bias, } \\
\text { measurement bias } \\
\text { and observer bias. }\end{array}$ \\
\hline $\begin{array}{l}\text { Alacrón } \\
\text { et al. }[28] \text {, } \\
2015\end{array}$ & $\begin{array}{l}\text { Outcomes: O1, } \\
\text { O2,O3. } \\
\text { Risk: Serious } \\
\text { SfJ: Critically } \\
\text { important } \\
\text { confounders } \\
\text { (pretreatment } \\
\text { overjet, soft } \\
\text { tissue variation) } \\
\text { not measured } \\
\text { and not adjusted } \\
\text { for in the } \\
\text { analysis. }\end{array}$ & $\begin{array}{l}\text { Outcomes: O1, } \\
\text { O2,O3. } \\
\text { Risk: Serious } \\
\text { SfJ: Selection into } \\
\text { the study was } \\
\text { related to interven- } \\
\text { tion and probably } \\
\text { the outcome. }\end{array}$ & $\begin{array}{l}\text { Outcomes: O1, } \\
\text { O2,O3. } \\
\text { Risk: Moderate } \\
\text { SfJ: Intervention } \\
\text { status is well } \\
\text { defined but data } \\
\text { were obtained } \\
\text { retrospectively. }\end{array}$ & $\begin{array}{l}\text { Outcomes: O1, } \\
\text { O2,O3. } \\
\text { Risk: Low } \\
\text { SfJ: No bias due to } \\
\text { departures from } \\
\text { intended intervention } \\
\text { is expected. }\end{array}$ & $\begin{array}{l}\text { Outcomes: O1, } \\
\text { O2,O3. } \\
\text { Risk: Moder- } \\
\text { ate } \\
\text { SfJ: Reasons } \\
\text { for missingness } \\
\text { (for baseline } \\
\text { confounders) } \\
\text { differ mini- } \\
\text { mally across } \\
\text { interventions } \\
\text { and missing } \\
\text { data were not } \\
\text { addressed in } \\
\text { the analysis. }\end{array}$ & $\begin{array}{l}\text { Outcomes: O1, } \\
\text { O2,O3. } \\
\text { Risk: Low } \\
\text { SfJ: Comparable } \\
\text { methods of out- } \\
\text { come assessment } \\
\text { between the 2 } \\
\text { groups, and blinded } \\
\text { assessor to } \\
\text { intervention status } \\
\text { and any error in } \\
\text { measuring the } \\
\text { outcome unrelated } \\
\text { to intervention } \\
\text { status. }\end{array}$ & $\begin{array}{l}\text { Outcomes: O1, } \\
\text { O2,O3. } \\
\text { Risk: Moderate } \\
\text { SfJ: Outcome } \\
\text { measurements and } \\
\text { analysis were } \\
\text { clearly defined, } \\
\text { internally and } \\
\text { externally consis- } \\
\text { tent, there was no } \\
\text { indication of } \\
\text { selection of the } \\
\text { reported analysis } \\
\text { from among } \\
\text { multiple analyses } \\
\text { and no indication of } \\
\text { selection of the } \\
\text { cohort or subgroups } \\
\text { for analysis and } \\
\text { reporting on the } \\
\text { basis of the results. }\end{array}$ & $\begin{array}{l}\text { Risk: Serious } \\
\text { SfJ: The study } \\
\text { has some impor- } \\
\text { tant problems, e.g: } \\
\text { serious risk of } \\
\text { selection bias } \\
\text { (residual con- } \\
\text { founding and in } \\
\text { the selection of } \\
\text { the participants). }\end{array}$ \\
\hline $\begin{array}{l}\text { Tuncer } \text { et al. } \\
{[18], 2009}\end{array}$ & $\begin{array}{l}\text { Outcomes: O1. } \\
\text { Risk: Serious } \\
\text { SfJ: one criti- } \\
\text { cally important } \\
\text { confounder } \\
\text { (ethnicity) not } \\
\text { measured and } \\
\text { not adjusted for } \\
\text { in the analysis. }\end{array}$ & $\begin{array}{l}\text { Outcomes: O1. } \\
\text { Risk: Serious } \\
\text { SfJ: Selection into } \\
\text { the study was } \\
\text { related to interven- } \\
\text { tion and probably } \\
\text { the outcome. }\end{array}$ & $\begin{array}{l}\text { Outcomes: O1. } \\
\text { Risk: Moderate } \\
\text { SfJ: Intervention } \\
\text { status is well } \\
\text { defined but data } \\
\text { were obtained } \\
\text { retrospectively. }\end{array}$ & $\begin{array}{l}\text { Outcomes: O1. } \\
\text { Risk: Serious } \\
\text { SfJ: Co-intervention is } \\
\text { apparent (OBP) and } \\
\text { not adjusted for in the } \\
\text { analysis. }\end{array}$ & $\begin{array}{l}\text { Outcomes: O1. } \\
\text { Risk: Moder- } \\
\text { ate } \\
\text { SfJ: Reasons } \\
\text { for missingness } \\
\text { (for baseline } \\
\text { confounder) } \\
\text { differ mini- } \\
\text { mally across } \\
\text { interventions } \\
\text { and missing } \\
\text { data were not } \\
\text { addressed in } \\
\text { the analysis. }\end{array}$ & $\begin{array}{l}\text { Outcomes: O1. } \\
\text { Risk: Moderate } \\
\text { SfJ: Comparable } \\
\text { method of outcome } \\
\text { assessment be- } \\
\text { tween the } 2 \text { groups, } \\
\text { outcome measure is } \\
\text { only minimally } \\
\text { influenced by } \\
\text { knowledge of } \\
\text { intervention status } \\
\text { and any systematic } \\
\text { error in measure- } \\
\text { ments only mini- } \\
\text { mally related to } \\
\text { intervention status. }\end{array}$ & $\begin{array}{l}\text { Outcomes: O1. } \\
\text { Risk: Moderate } \\
\text { SfJ: Outcome } \\
\text { measurements and } \\
\text { analysis were } \\
\text { clearly defined, } \\
\text { internally and } \\
\text { externally consis- } \\
\text { tent, there was no } \\
\text { indication of } \\
\text { selection of the } \\
\text { reported analysis } \\
\text { from among } \\
\text { multiple analyses } \\
\text { and no indication of } \\
\text { selection of the } \\
\text { cohort or subgroups } \\
\text { for analysis and } \\
\text { reporting on the } \\
\text { basis of the results. }\end{array}$ & $\begin{array}{l}\text { Risk: Serious } \\
\text { SfJ: The study } \\
\text { has some impor- } \\
\text { tant problems, e.g: } \\
\text { serious risk of } \\
\text { selection bias } \\
\text { (residual con- } \\
\text { founding, selec- } \\
\text { tion of the partici- } \\
\text { pants), informa- } \\
\text { tion bias and } \\
\text { performance bias. }\end{array}$ \\
\hline $\begin{array}{l}\text { Gökalp and } \\
\text { Kurt [29], } \\
2005 .\end{array}$ & $\begin{array}{l}\text { Outcomes: } \\
\text { O1,O2. } \\
\text { Risk: Serious } \\
\text { SfJ: critically } \\
\text { important } \\
\text { domains (ethnic- } \\
\text { ity, age, skeletal } \\
\text { Class of maloc- } \\
\text { clusion) not } \\
\text { measured and } \\
\text { not adjusted for } \\
\text { in the analysis. }\end{array}$ & $\begin{array}{l}\text { Outcomes: } \\
\text { O1,O2. } \\
\text { Risk: Serious } \\
\text { SfJ: Selection into } \\
\text { the study was } \\
\text { related to interven- } \\
\text { tion and probably } \\
\text { the outcome. }\end{array}$ & $\begin{array}{l}\text { Outcomes: } \\
\text { O1,O2. } \\
\text { Risk: Moderate } \\
\text { SfJ: Intervention } \\
\text { status is well } \\
\text { defined but data } \\
\text { were obtained } \\
\text { retrospectively. }\end{array}$ & $\begin{array}{l}\text { Outcomes: O1,O2. } \\
\text { Risk: Low } \\
\text { SfJ: No bias due to } \\
\text { departures from } \\
\text { intended intervention } \\
\text { is expected. }\end{array}$ & $\begin{array}{l}\text { Outcomes: } \\
\text { O1,O2. } \\
\text { Risk: Moder- } \\
\text { ate } \\
\text { SfJ: Reasons } \\
\text { for missingness } \\
\text { (missing data } \\
\text { on baseline } \\
\text { confounders) } \\
\text { differ mini- } \\
\text { mally across } \\
\text { interventions } \\
\text { and missing } \\
\text { data were not } \\
\text { addressed in } \\
\text { the analysis. }\end{array}$ & $\begin{array}{l}\text { Outcomes: O1,O2. } \\
\text { Risk: Moderate } \\
\text { SfJ: Comparable } \\
\text { method of outcome } \\
\text { assessment be- } \\
\text { tween the } 2 \text { groups, } \\
\text { outcome measure } \\
\text { only minimally } \\
\text { influenced by } \\
\text { knowledge of } \\
\text { intervention status } \\
\text { and any systematic } \\
\text { error in measure- } \\
\text { ments only mini- } \\
\text { mally related to } \\
\text { intervention status. }\end{array}$ & $\begin{array}{l}\text { Outcomes: O1. } \\
\text { Risk: Moderate } \\
\text { SfJ: Outcome } \\
\text { measurements and } \\
\text { analysis were } \\
\text { clearly defined, } \\
\text { internally and } \\
\text { externally consis- } \\
\text { tent, there was no } \\
\text { indication of } \\
\text { selection of the } \\
\text { reported analysis } \\
\text { from among } \\
\text { multiple analyses } \\
\text { and no indication of } \\
\text { selection of the } \\
\text { cohort or subgroups } \\
\text { for analysis and } \\
\text { reporting on the } \\
\text { basis of the results. }\end{array}$ & $\begin{array}{l}\text { Risk: Serious } \\
\text { SfJ: The study } \\
\text { has some impor- } \\
\text { tant problems, e.g: } \\
\text { serious risk of } \\
\text { selection bias } \\
\text { (residual con- } \\
\text { founding and in } \\
\text { the selection of } \\
\text { the participants). }\end{array}$ \\
\hline
\end{tabular}




\begin{tabular}{|c|c|c|c|c|c|c|c|c|}
\hline $\begin{array}{l}\text { Sakamoto } \\
\text { et al. } \\
\text { [23], } 1984 .\end{array}$ & $\begin{array}{l}\text { Outcomes: O1. } \\
\text { Risk: Serious } \\
\text { SfJ: one criti- } \\
\text { cally important } \\
\text { domain (age) } \\
\text { not adjusted for } \\
\text { in the analysis } \\
\text { (skeletal matur- } \\
\text { ity stage not } \\
\text { addressed). }\end{array}$ & $\begin{array}{l}\text { Outcomes: O1. } \\
\text { Risk: Serious } \\
\text { SfJ: Selection into } \\
\text { the study was } \\
\text { related to interven- } \\
\text { tion and probably } \\
\text { the outcome. }\end{array}$ & $\begin{array}{l}\text { Outcomes: O1. } \\
\text { Risk: Serious } \\
\text { SfJ: Intervention } \\
\text { status is not well } \\
\text { defined (skeletal } \\
\text { maturity stage, } \\
\text { number of patients } \\
\text { with additional } \\
\text { lingual arch) and } \\
\text { major aspects of } \\
\text { the assignments of } \\
\text { intervention were } \\
\text { determined in a } \\
\text { way that could } \\
\text { have been affected } \\
\text { by knowledge of } \\
\text { the outcome. }\end{array}$ & $\begin{array}{l}\text { Outcomes: O1. } \\
\text { Risk: Serious } \\
\text { SfJ:Co-intervention } \\
\text { (lingual arch) is } \\
\text { apparent and not } \\
\text { adjusted for in the } \\
\text { analysis. }\end{array}$ & $\begin{array}{l}\text { Outcomes: O1. } \\
\text { Risk: Serious } \\
\text { SfJ: Because } \\
\text { the reported } \\
\text { results corre- } \\
\text { spond to the } 26 \\
\text { treated patients, } \\
\text { while the } \\
\text { untreated } \\
\text { control group } \\
\text { of } 423 \text { patients } \\
\text { is used sup- } \\
\text { plementarily to } \\
\text { illustrate the } \\
\text { aforementioned } \\
\text { results, judge- } \\
\text { ment is basi- } \\
\text { cally based on } \\
\text { the missing } \\
\text { data regarding } \\
\text { the treated } \\
\text { patients (data } \\
\text { on baseline } \\
\text { characteristics } \\
\text { and con- } \\
\text { founders). }\end{array}$ & $\begin{array}{l}\text { Outcomes: O1. } \\
\text { Risk: Serious } \\
\text { SfJ: Outcome } \\
\text { measure likely to } \\
\text { be influenced by } \\
\text { knowledge of the } \\
\text { intervention status } \\
\text { and assessed by } \\
\text { outcome assessors } \\
\text { aware of the } \\
\text { received interven- } \\
\text { tion. Any error in } \\
\text { measuring the } \\
\text { outcomes was also } \\
\text { related to interven- } \\
\text { tion. }\end{array}$ & $\begin{array}{l}\text { Outcomes: O1. } \\
\text { Risk: Serious } \\
\text { SfJ: Because there } \\
\text { is moderate risk of } \\
\text { bias in selective } \\
\text { reporting of the } \\
\text { results of the study, } \\
\text { but critical risk only } \\
\text { for the supplemen- } \\
\text { tary comparison to } \\
\text { untreated controls } \\
\text { (1 patient compared } \\
\text { to } 423 \text { controls). }\end{array}$ & $\begin{array}{l}\text { Risk: Serious } \\
\text { SfJ: The study } \\
\text { has some impor- } \\
\text { tant problems, e.g: } \\
\text { serious risk of } \\
\text { selection bias } \\
\text { (residual con- } \\
\text { founding, selec- } \\
\text { tion of the partici- } \\
\text { pants),information } \\
\text { bias, performance } \\
\text { bias, detection } \\
\text { bias, measurement } \\
\text { bias and observer } \\
\text { bias, outcome } \\
\text { reporting bias. }\end{array}$ \\
\hline $\begin{array}{l}\text { Deguchi and } \\
\text { McNamara } \\
{[26], 1999 .}\end{array}$ & $\begin{array}{l}\text { Outcomes: } \\
\text { O1,O2 } \\
\text { Risk: Low } \\
\text { SfJ: No bias due } \\
\text { to confounding } \\
\text { is expected. }\end{array}$ & $\begin{array}{l}\text { Outcomes: } \\
\text { O1,O2. } \\
\text { Risk: Serious } \\
\text { SfJ: Selection into } \\
\text { the study was } \\
\text { related to interven- } \\
\text { tion and probably } \\
\text { the outcome. }\end{array}$ & $\begin{array}{l}\text { Outcomes: } \\
\text { O1,O2. } \\
\text { Risk: Moderate } \\
\text { SfJ: Intervention } \\
\text { status is well } \\
\text { defined, but data } \\
\text { were retrospec- } \\
\text { tively obtained. }\end{array}$ & $\begin{array}{l}\text { Outcomes: O1, O2. } \\
\text { Risk: Serious } \\
\text { SfJ: Co-intervention is } \\
\text { apparent (upper } \\
\text { lingual arch) and not } \\
\text { adjusted for in the } \\
\text { analysis. }\end{array}$ & $\begin{array}{l}\text { Outcomes: } \\
\text { O1,O2. } \\
\text { Risk: Low } \\
\text { SfJ: Data were } \\
\text { reasonably } \\
\text { complete. }\end{array}$ & $\begin{array}{l}\text { Outcomes: O1,O2. } \\
\text { Risk: Moderate } \\
\text { SfJ: Comparable } \\
\text { method of outcome } \\
\text { assessment be- } \\
\text { tween the } 2 \text { groups, } \\
\text { outcome measure } \\
\text { only minimally } \\
\text { influenced by } \\
\text { knowledge of } \\
\text { intervention status } \\
\text { (no blinding } \\
\text { reported) and any } \\
\text { systematic error in } \\
\text { measurements only } \\
\text { minimally related } \\
\text { to intervention } \\
\text { status. }\end{array}$ & $\begin{array}{l}\text { Outcomes: O1,O2. } \\
\text { Risk: Moderate } \\
\text { SfJ: Outcome } \\
\text { measurements and } \\
\text { analysis were } \\
\text { clearly defined, } \\
\text { internally and } \\
\text { externally consis- } \\
\text { tent, there was no } \\
\text { indication of } \\
\text { selection of the } \\
\text { reported analysis } \\
\text { from among } \\
\text { multiple analyses } \\
\text { and no indication of } \\
\text { selection of the } \\
\text { cohort or subgroups } \\
\text { for analysis and } \\
\text { reporting on the } \\
\text { basis of the results. }\end{array}$ & $\begin{array}{l}\text { Risk: Serious } \\
\text { SfJ: The study } \\
\text { has some impor- } \\
\text { tant problems, e.g: } \\
\text { serious risk of } \\
\text { selection bias } \\
\text { (selection of the } \\
\text { partici- } \\
\text { pants),information } \\
\text { bias and perform- } \\
\text { ance bias. }\end{array}$ \\
\hline $\begin{array}{l}\text { Akin } \text { et al. } \\
\text { [19], 2015. }\end{array}$ & $\begin{array}{l}\text { Outcomes: } \\
\text { O1,O2,O3. } \\
\text { Risk: Serious } \\
\text { SfJ: Critically } \\
\text { important } \\
\text { domains (ethnic- } \\
\text { ity, individual } \\
\text { soft-tissue } \\
\text { variation, pre- } \\
\text { treatment } \\
\text { overjet) not } \\
\text { measured and } \\
\text { not adjusted for } \\
\text { in the analysis. }\end{array}$ & $\begin{array}{l}\text { Outcomes: } \\
\text { O1,O2,O3. } \\
\text { Risk: Serious } \\
\text { SfJ: Selection into } \\
\text { the study was } \\
\text { related to interven- } \\
\text { tion (intervention } \\
\text { was known and } \\
\text { blinding was only } \\
\text { performed for the } \\
\text { selection of } 15 \\
\text { cases for each } \\
\text { group) and proba- } \\
\text { bly the outcome. }\end{array}$ & $\begin{array}{l}\text { Outcomes: } \\
\text { O1,O2,O3. } \\
\text { Risk: Serious } \\
\text { SfJ:Intervention } \\
\text { status is not well } \\
\text { defined (not } \\
\text { declared whether } \\
\text { CC therapy was } \\
\text { continued or ended } \\
\text { by the time fixed } \\
\text { appliances were } \\
\text { placed and for } \\
\text { what reason the } \\
\text { flat Essix plate } \\
\text { was used). }\end{array}$ & $\begin{array}{l}\text { Outcomes: O1,O2,O3. } \\
\text { Risk: Serious } \\
\text { SfJ: Co-interventions } \\
\text { are apparent (flat Essix } \\
\text { plate, possibly simul- } \\
\text { taneous use of fixed } \\
\text { appliances) and not } \\
\text { adjusted for in the } \\
\text { analysis. }\end{array}$ & $\begin{array}{l}\text { Outcomes: } \\
\text { O1,O2,O3. } \\
\text { Risk: Moder- } \\
\text { ate } \\
\text { SfJ: Missing } \\
\text { data (on } \\
\text { baseline } \\
\text { confounders) } \\
\text { were not } \\
\text { addressed in } \\
\text { the analysis } \\
\text { and reasons for } \\
\text { missingness } \\
\text { differ mini- } \\
\text { mally across } \\
\text { interventions. }\end{array}$ & $\begin{array}{l}\text { Outcomes: } \\
\text { O1,O2,O3. } \\
\text { Risk: Moderate } \\
\text { SfJ: Comparable } \\
\text { method of outcome } \\
\text { assessment be- } \\
\text { tween the groups, } \\
\text { outcome measure } \\
\text { only minimally } \\
\text { influenced by } \\
\text { knowledge of } \\
\text { intervention status } \\
\text { (no blinding } \\
\text { reported) and any } \\
\text { systematic error in } \\
\text { measurements only } \\
\text { minimally related } \\
\text { to intervention } \\
\text { status. }\end{array}$ & $\begin{array}{l}\text { Outcomes: } \\
\text { O1,O2,O3. } \\
\text { Risk: Moderate } \\
\text { SfJ: Outcome } \\
\text { measurements and } \\
\text { analysis were } \\
\text { clearly defined, } \\
\text { internally and } \\
\text { externally consis- } \\
\text { tent, there was no } \\
\text { indication of } \\
\text { selection of the } \\
\text { reported analysis } \\
\text { from among } \\
\text { multiple analyses } \\
\text { and no indication of } \\
\text { selection of the } \\
\text { cohort or subgroups } \\
\text { for analysis and } \\
\text { reporting on the } \\
\text { basis of the results. }\end{array}$ & $\begin{array}{l}\text { Risk: Serious } \\
\text { SfJ: The study } \\
\text { has some impor- } \\
\text { tant problems, e.g: } \\
\text { serious risk of } \\
\text { selection bias } \\
\text { (residual con- } \\
\text { founding, selec- } \\
\text { tion of the partici- } \\
\text { pants), informa- } \\
\text { tion bias and } \\
\text { performance bias. }\end{array}$ \\
\hline $\begin{array}{l}\text { Lin et al. [20], } \\
2007 .\end{array}$ & $\begin{array}{l}\text { Outcomes: } \\
\text { O1,O2 } \\
\text { Risk: Serious } \\
\text { SfJ: Critically } \\
\text { important } \\
\text { domain (ethnic- } \\
\text { ity) not meas- } \\
\text { ured and not } \\
\text { adjusted for in }\end{array}$ & $\begin{array}{l}\text { Outcomes: } \\
\text { O1,O2. } \\
\text { Risk: Serious } \\
\text { SfJ: Selection into } \\
\text { the study was } \\
\text { related to interven- } \\
\text { tion and probably } \\
\text { the outcome. }\end{array}$ & $\begin{array}{l}\text { Outcomes: O1,O2 } \\
\text { Risk: Moderate } \\
\text { SfJ: Intervention } \\
\text { status is well } \\
\text { defined, but data } \\
\text { were obtained } \\
\text { retrospectively. }\end{array}$ & $\begin{array}{l}\text { Outcomes: O1,O2 } \\
\text { Risk: Serious } \\
\text { SfJ: Co-intervention } \\
\text { (OMA) is apparent } \\
\text { and not adjusted for in } \\
\text { the analysis.. }\end{array}$ & $\begin{array}{l}\text { Outcomes: } \\
\text { O1,O2 } \\
\text { Risk: Moder- } \\
\text { ate } \\
\text { SfJ: Reasons } \\
\text { for missingness } \\
\text { differ mini- } \\
\text { mally across } \\
\text { the } 2 \text { groups }\end{array}$ & $\begin{array}{l}\text { Outcomes: O1,O2 } \\
\text { Risk: Moderate } \\
\text { SfJ: Comparable } \\
\text { method of outcome } \\
\text { assessment be- } \\
\text { tween the groups, } \\
\text { outcome measure } \\
\text { only minimally } \\
\text { influenced by }\end{array}$ & $\begin{array}{l}\text { Outcomes: O1,O2. } \\
\text { Risk: Moderate } \\
\text { SfJ: Outcome } \\
\text { measurements and } \\
\text { analysis were } \\
\text { clearly defined, } \\
\text { internally and } \\
\text { externally consis- } \\
\text { tent, there was no }\end{array}$ & $\begin{array}{l}\text { Risk: Serious } \\
\text { SfJ: The study } \\
\text { has some impor- } \\
\text { tant problems, } \text { e.g: } \\
\text { serious risk of } \\
\text { selection bias } \\
\text { (residual con- } \\
\text { founding, selec- } \\
\text { tion of the partici- }\end{array}$ \\
\hline
\end{tabular}




\begin{tabular}{|c|c|c|c|c|c|c|c|c|}
\hline & the analysis. & & & & $\begin{array}{l}\text { and missing } \\
\text { data were not } \\
\text { addressed in } \\
\text { the analysis. }\end{array}$ & $\begin{array}{l}\text { knowledge of } \\
\text { intervention status } \\
\text { (no blinding } \\
\text { reported) and any } \\
\text { systematic error in } \\
\text { measurements only } \\
\text { minimally related } \\
\text { to intervention } \\
\text { status. }\end{array}$ & $\begin{array}{l}\text { indication of } \\
\text { selection of the } \\
\text { reported analysis } \\
\text { from among } \\
\text { multiple analyses } \\
\text { and no indication of } \\
\text { selection of the } \\
\text { cohort or subgroups } \\
\text { for analysis and } \\
\text { reporting on the } \\
\text { basis of the results. }\end{array}$ & $\begin{array}{l}\text { pants), perform- } \\
\text { ance bias. }\end{array}$ \\
\hline $\begin{array}{l}\text { Barrett et al. } \\
{[21], 2010 .}\end{array}$ & \begin{tabular}{|l|} 
Outcomes: O1, \\
O2,O3. \\
Risk: Serious \\
SfJ: Critically \\
important \\
confounder \\
(Skeletal Class \\
of malocclusion) \\
not measured \\
and not adjusted \\
for in the \\
analysis.
\end{tabular} & \begin{tabular}{|l|} 
Outcomes: \\
O1,O2,O3. \\
Risk: Serious \\
SfJ: Selection into \\
the study was \\
related to interven- \\
tion and probably \\
the outcome.
\end{tabular} & $\begin{array}{l}\text { Outcomes: O1, } \\
\text { O2,O3. } \\
\text { Risk: Moderate } \\
\text { SfJ: Intervention } \\
\text { status is well } \\
\text { defined, but data } \\
\text { were retrospec- } \\
\text { tively obtained. }\end{array}$ & $\begin{array}{l}\text { Outcomes: O1, } \\
\text { O2,O3. } \\
\text { Risk: Serious } \\
\text { SfJ: Co-intervention is } \\
\text { apparent }(\mathrm{QH}) \text { and not } \\
\text { adjusted for in the } \\
\text { analysis. }\end{array}$ & $\begin{array}{l}\text { Outcomes: O1, } \\
\text { O2,O3. } \\
\text { Risk: Moder- } \\
\text { ate } \\
\text { SfJ: Reasons } \\
\text { for missingness } \\
\text { differ mini- } \\
\text { mally across } \\
\text { interventions } \\
\text { and missing } \\
\text { data (on } \\
\text { baseline } \\
\text { confounder) } \\
\text { were not } \\
\text { addressed in } \\
\text { the analysis. }\end{array}$ & $\begin{array}{l}\text { Outcomes: O1, } \\
\text { O2,O3. } \\
\text { Risk: Moderate } \\
\text { SfJ: Comparable } \\
\text { method of outcome } \\
\text { assessment be- } \\
\text { tween the groups, } \\
\text { outcome measure } \\
\text { only minimally } \\
\text { influenced by } \\
\text { knowledge of } \\
\text { intervention status } \\
\text { (no blinding } \\
\text { reported) and any } \\
\text { systematic error in } \\
\text { measurements only } \\
\text { minimally related } \\
\text { to intervention } \\
\text { status. }\end{array}$ & $\begin{array}{l}\text { Outcomes: } \\
\text { O1,O2,O3. } \\
\text { Risk: Moderate } \\
\text { SfJ: Outcome } \\
\text { measurements and } \\
\text { analysis were } \\
\text { clearly defined, } \\
\text { internally and } \\
\text { externally consis- } \\
\text { tent, there was no } \\
\text { indication of } \\
\text { selection of the } \\
\text { reported analysis } \\
\text { from among } \\
\text { multiple analyses } \\
\text { and no indication of } \\
\text { selection of the } \\
\text { cohort or subgroups } \\
\text { for analysis and } \\
\text { reporting on the } \\
\text { basis of the results. }\end{array}$ & $\begin{array}{l}\text { Risk: Serious } \\
\text { SfJ: The study } \\
\text { has some impor- } \\
\text { tant problems, e.g: } \\
\text { serious risk of } \\
\text { selection bias } \\
\text { (residual con- } \\
\text { founding, selec- } \\
\text { tion of the partici- } \\
\text { pants) and } \\
\text { performance bias. }\end{array}$ \\
\hline $\begin{array}{l}\text { Abu Alhaija } \\
\text { and } \\
\text { Richardson } \\
{[24], 1999 .}\end{array}$ & $\begin{array}{l}\text { Outcomes: O1, } \\
\text { O2,O3. } \\
\text { Risk: Serious } \\
\text { SfJ: Critically } \\
\text { important } \\
\text { confounders } \\
\text { (ethnicity, age, } \\
\text { Skeletal Class of } \\
\text { malocclusion } \\
\text { and soft-tissue } \\
\text { variation) not } \\
\text { measured and } \\
\text { not adjusted for } \\
\text { in the analysis. }\end{array}$ & $\begin{array}{l}\text { Outcomes: } \\
\text { O1,O2,O3. } \\
\text { Risk: Serious } \\
\text { SfJ: Selection into } \\
\text { the study was } \\
\text { related to interven- } \\
\text { tion and probably } \\
\text { the outcome. }\end{array}$ & $\begin{array}{l}\text { Outcomes: O1, } \\
\text { O2,O3. } \\
\text { Risk: Moderate } \\
\text { SfJ: Intervention } \\
\text { status is well } \\
\text { defined, but data } \\
\text { were obtained } \\
\text { retrospectively. }\end{array}$ & $\begin{array}{l}\text { Outcomes: O1, } \\
\text { O2,O3. } \\
\text { Risk: Serious } \\
\text { SfJ: Co-intervention is } \\
\text { apparent (URA) and } \\
\text { not adjusted for in the } \\
\text { analysis. }\end{array}$ & $\begin{array}{l}\text { Outcomes: O1, } \\
\text { O2,O3. } \\
\text { Risk: Moder- } \\
\text { ate } \\
\text { SfJ: Reasons } \\
\text { for missingness } \\
\text { differ mini- } \\
\text { mally across } \\
\text { the } 2 \text { groups } \\
\text { and missing } \\
\text { data (on } \\
\text { baseline } \\
\text { confounders) } \\
\text { were not } \\
\text { addressed in } \\
\text { the analysis. }\end{array}$ & $\begin{array}{l}\text { Outcomes: O1, } \\
\text { O2,O3. } \\
\text { Risk: Moderate } \\
\text { SfJ: Comparable } \\
\text { method of outcome } \\
\text { assessment be- } \\
\text { tween the groups, } \\
\text { outcome measure } \\
\text { only minimally } \\
\text { influenced by } \\
\text { knowledge of } \\
\text { intervention status } \\
\text { (no blinding } \\
\text { reported) and any } \\
\text { systematic error in } \\
\text { measurements only } \\
\text { minimally related } \\
\text { to intervention } \\
\text { status. }\end{array}$ & $\begin{array}{l}\text { Outcomes: O1, } \\
\text { O2,O3. } \\
\text { Risk: Moderate } \\
\text { SfJ: Outcome } \\
\text { measurements and } \\
\text { analysis were } \\
\text { clearly defined, } \\
\text { internally and } \\
\text { externally consis- } \\
\text { tent, there was no } \\
\text { indication of } \\
\text { selection of the } \\
\text { reported analysis } \\
\text { from among } \\
\text { multiple analyses } \\
\text { and no indication of } \\
\text { selection of the } \\
\text { cohort or subgroups } \\
\text { for analysis and } \\
\text { reporting on the } \\
\text { basis of the results. }\end{array}$ & $\begin{array}{l}\text { Risk: Serious } \\
\text { SfJ: The study } \\
\text { has some impor- } \\
\text { tant problems, e.g: } \\
\text { serious risk of } \\
\text { selection bias } \\
\text { (residual con- } \\
\text { founding, selec- } \\
\text { tion of the partici- } \\
\text { pants) and per- } \\
\text { formance bias. }\end{array}$ \\
\hline $\begin{array}{l}\text { Abdelanby } \\
\text { and Nassar } \\
\text { [22], 2010. }\end{array}$ & \begin{tabular}{|l|} 
Outcomes: \\
O1,O2 \\
Risk: Serious \\
SfJ: Critically \\
important \\
domain (ethnic- \\
ity) not meas- \\
ured and not \\
adjusted for in \\
the analysis.
\end{tabular} & $\begin{array}{l}\text { Outcomes: } \\
\text { O1,O2. } \\
\text { Risk: Serious } \\
\text { SfJ: Selection into } \\
\text { the study was } \\
\text { related to interven- } \\
\text { tion and probably } \\
\text { the outcome. }\end{array}$ & $\begin{array}{l}\text { Outcomes: O1,O2 } \\
\text { Risk: Moderate } \\
\text { SfJ: Intervention } \\
\text { status is well } \\
\text { defined but data } \\
\text { were retrospec- } \\
\text { tively obtained. }\end{array}$ & $\begin{array}{l}\text { Outcomes: } \mathrm{O} 1, \mathrm{O} 2 \\
\text { Risk: Serious } \\
\text { SfJ: Co-intervention is } \\
\text { apparent (utilization of } \\
\text { force magnitude) and } \\
\text { not adjusted for in the } \\
\text { analysis. }\end{array}$ & $\begin{array}{l}\text { Outcomes: } \\
\text { O1,O2 } \\
\text { Risk: Moder- } \\
\text { ate } \\
\text { SfJ: Reasons } \\
\text { for missingness } \\
\text { differ mini- } \\
\text { mally across } \\
\text { interventions } \\
\text { and missing } \\
\text { data (on } \\
\text { baseline } \\
\text { confounder) } \\
\text { were not } \\
\text { addressed in } \\
\text { the analysis. }\end{array}$ & $\begin{array}{l}\text { Outcomes: O1,O2 } \\
\text { Risk: Moderate } \\
\text { SfJ: Comparable } \\
\text { method of outcome } \\
\text { assessment be- } \\
\text { tween the groups, } \\
\text { outcome measure } \\
\text { only minimally } \\
\text { influenced by } \\
\text { knowledge of } \\
\text { intervention status } \\
\text { (no blinding } \\
\text { reported) and any } \\
\text { systematic error in } \\
\text { measurements only } \\
\text { minimally related } \\
\text { to intervention } \\
\text { status. }\end{array}$ & $\begin{array}{l}\text { Outcomes: O1, O2 } \\
\text { Risk: Moderate } \\
\text { SfJ: Outcome } \\
\text { measurements and } \\
\text { analysis were } \\
\text { clearly defined, } \\
\text { internally and } \\
\text { externally consis- } \\
\text { tent, there was no } \\
\text { indication of } \\
\text { selection of the } \\
\text { reported analysis } \\
\text { from among } \\
\text { multiple analyses } \\
\text { and no indication of } \\
\text { selection of the } \\
\text { cohort or subgroups } \\
\text { for analysis and } \\
\text { reporting on the } \\
\text { basis of the results. }\end{array}$ & $\begin{array}{l}\text { Risk: Serious } \\
\text { SfJ: The study } \\
\text { has some impor- } \\
\text { tant problems, e.g: } \\
\text { serious risk of } \\
\text { selection bias } \\
\text { (residual con- } \\
\text { founding, selec- } \\
\text { tion of the partici- } \\
\text { pants) and per- } \\
\text { formance bias. }\end{array}$ \\
\hline
\end{tabular}

${ }^{a}$ The cited references of the articles in the first column of the table correspond to the numbered references in the text.Y.o.P: indicates year of publication, O1: skeletal effects, O2: dentoalveolar effects, O3: soft-tissue effects, SfJ: support for judgement, OBP: occlusal bite plate, RHG: reversed headgear, CC: chin-cup, OMA: occipitomental anchorage appliance of maxillary protraction combined with chin-cup traction, QH: quad-helix, URA: upper removable appliance. 
Although this was not the first time that this issue has been addressed in the literature, researchers in previous systematic reviews did not investigate the long-term effects of chin-cup therapy $[2,10,12]$, the soft tissue changes [2, $10,12]$ and the adolescence as a study growth period [10].

Our search strategy resulted in only CCTs, thirteen of retrospective [8, 17 - 28] and one of prospective design [29], with no RCT found. One possible reason is that RCTs are not common in orthodontics, since various parameters are required. These include patient/observer blinding to treatment and ethical matters regarding the control group whose decision of participation is negatively affected by receiving no treatment.

The final studies were cohort studies with weaknesses due to the serious risk of bias, as it is described in detail in Table 4. All the studies were found to have selection bias, as the selection of both participants and controls was related to the received intervention and likely to the outcomes.

Furthermore, the studies were judged to have a serious risk of bias concerning the outcomes' measurements when the knowledge of the received intervention by the assessors was likely to influence the outcomes in a way that it could cause statistically significant differences. Thus, three studies [8, 23, 27] received that characterization, as the way that the outcome measure was conducted, was considered to have the potential to significantly affect the outcomes. The risk of bias was judged low, when blinding of outcome assessors was reported [25, 28]. These studies were considered comparable to a well-performed randomized trial with regard to this domain, according to the ACROBAT-NRSI [13]. Consequently, studies pertaining to neither categories, were judged to have a moderate risk of bias [17 - 22, 24, 26, 29]. Based on the ACROBAT-NRSI [13] in these studies the outcome measure was only minimally influenced by the awareness of the received intervention and any error in measuring the outcome was only minimally related to intervention status. The methods of outcome assessment were comparable across intervention groups both for the studies with a moderate and a low risk of bias.

Another weakness of the observational studies, both prospective and retrospective, is the presence of confounders. In the present systematic review, we considered confounders, all those factors that were possibly related to the chin-cup therapy and could cause significant changes in the results. Ethnicity was needed to be taken into account, as Class III malocclusion is more frequently seen in Asian populations [1, 7, 14 - 16] and consequently these patients may be more often treated with chin-cups. Moreover, patients of Asian ancestry may present different baseline characteristics, as well as a different growth pattern than other populations, thus significantly affecting the results. The age of the participants in relation to their skeletal maturity stage was also accounted for. This was mainly due the fact that the prepubertal patients may present different results from patients that are in the peak of their growth or later. Skeletal Class of malocclusion was considered a confounder when there was doubt on whether the treated and/or the control group had skeletal Class III malocclusion or when some controls had skeletal Class I. Soft-tissue individual variation in thickness and in tension was co-estimated, since it could affect the reported results regarding the soft-tissue changes, as it was highlighted by Arman et al. [17] and Alacrón et al. [28]. Finally, pre-treatment overjet was also considered a confounder.

In addition, co-interventions were addressed. More specifically, the use of additional appliances, such as a lingual arch to flare the maxillary incisors [23, 26] or a quad-helix appliance [21] were considered critically important cointerventions that could significantly alter the outcomes. To illustrate this, in four studies $[17,19,20,24]$ the declared proclination of the upper incisors [17, 19, 20, 24] followed by forward movement of the soft-tissue point A [17] and the upper lip [17, 19, 24] was probably the result of an additional occlusal bite plate [17, 19], an upper removable appliance [24] and of the combination of maxillary protraction and chin-cup traction in an occipitomental anchorage appliance [20]. The significantly increased overjet [17, 19 - 21, 24] that was noted, was expected to be a result of the aforementioned additional appliances. However, it was also reported in studies where patients, treated solely with chincups, were contrasted to untreated controls $[8,28,29]$. One possible reason is the occlusal interferences in the transition of the occlusion from a one with underjet to one with overjet [8], that flare the upper incisors. It could also be the result of the significant retroclination of lower incisors caused by the chin-cup [8, 22]. At last, utilization of force magnitude was considered a co-intervention as well, since significant reduction in ramus height was noted when lighter force in chin-cup traction was used [22].

Patients under chin-cup therapy showed an improved facial profile, merely induced by the backward and downward rotation of the mandible [17 - 20, 26, 28]. This was documented by a decrease in the SNB [17 - 22] and closure of the gonial angle [20, 23, 25, 26]. It was also correlated with an increase in the anterior facial height [17, 18, 22, 24]. In contrast, Wendell et al. [27] recorded significant decreases in the anterior face height during chin-cup therapy in 
comparison with untreated controls. This was attributed to the $43 \%$ decrease in the downward displacement of pogonion during treatment, which was not stable at the post-treatment observation, when it was increased by $60 \%$ [27]. The backward and downward rotation of the mandible was correlated with an increase in the ANB angle as well [17, 19, 21 - 23]. However, there is ambiguity in whether only the mandible or both the mandible and the maxilla are responsible for this.

Moreover, there is controversy among researchers regarding the retardation of the mandibular growth during chincup therapy. A significant reduction of the mandibular length (ramal, body and total length) was reported in five studies [22, 23, 26 - 28] indicating an improvement in the skeletal profile of the treated patients. Most interesting were the findings of Wendell et al. [27], whose study presented a reduction in absolute mandibular length, which continued after the end of the active treatment. In contrast, the studies of Gökalp and Kurt [29] and Abu Alhaija and Richardson [24] showed significantly increased mandibular body [24, 29] and total mandibular length [24]. Gökalp and Kurt [29] attributed these alterations in the forward bending of the condyle, as a result of bone deposition between the condylar head and neck during chin-cup therapy.

The aforementioned controversy led to further investigating attempts by researchers in order to elucidate the role of chin-cup therapy in the retardation of mandibular growth. Similar attempts were also made to assess the potential influence of chin-cup therapy in the appearance of Temporomandibular Joint Disorders (TMD). It has been speculated that internal derangement of the TMJ is likely to occur due to the direct application of the backward chin-cup's force on the mandibular condyle [7]. This was recently evaluated in a systematic review [7] by Zurfluh et al. who, interestingly, concluded that despite the craniofacial adaptations induced by chin-cups in patients with Class III malocclusion, chincup therapy does not constitute a risk factor for the development of TMD, as the existence of insufficient or low-quality evidence in the literature do not allow clear statements regarding the influence of chin-cup treatment on the TMJ. Nevertheless, they related TMD with age and a stressful lifestyle that seem to differentiate the effects imposed on TMJ.

As for the soft-tissue effects, although confounding was evident, the documented results indicate a general softtissue profile improvement when the chin-cup is used in skeletal Class III patients. However, in the lack of studies that evaluate the long-term stability of the aforementioned changes, no definite conclusions can be reached.

In the basis of these manifestations, it is evident that the effects of chin-cup therapy both in the short-and especially in the long-term need further investigation and better substantiation with more high-quality evidence to draw reliable conclusions.

\section{CONCLUSION}

In summary, the present systematic review shows that the chin-cup therapy can be considered for the short-term treatment of growing patients with Class III malocclusion. More specifically, the following are evident:

- The skeletal profile is improved, as it is confirmed by significant changes in measured variables, which indicate a downward and backward rotation of the mandible.

- Favorable dento-alveolar changes, such as a significant increase in overjet are also observed. However, data need to be carefully interpreted in the presence of co-interventions, such as additional appliances that could have an impact on the outcomes.

- The soft tissues show a general improvement in the facial profile, following the accompanying skeletal and dento-alveolar changes, but with uncertain long-term stability.

Nevertheless, existing limitations that do not permit a clear judgement need to be taken into account. The unclear role of chin-cup therapy in the retardation of mandibular growth, the need for further investigation of the long-term effectiveness and the general lack of high quality evidence suggest cautious interpretation of the reported findings and highlight the need for future research with more high-quality evidence-based clinical trials, in order to draw reliable conclusions.

\section{CONFLICT OF INTEREST}

The authors confirm that this article content has no conflict of interest.

\section{ACKNOWLEDGEMENTS}

Declared none. 


\section{REFERENCES}

[1] Toffol LD, Pavoni C, Baccetti T, Franchi L, Cozza P. Orthopedic treatment outcomes in Class III malocclusion. A systematic review. Angle Orthod 2008; 78(3): 561-73.

[http://dx.doi.org/10.2319/030207-108.1] [PMID: 18416617]

[2] Liu ZP, Li CJ, Hu HK, Chen JW, Li F, Zou SJ. Efficacy of short-term chincup therapy for mandibular growth retardation in Class III malocclusion. Angle Orthod 2011; 81(1): 162-8. [http://dx.doi.org/10.2319/050510-244.1] [PMID: 20936970]

[3] Gelgör IE, Karaman AI. Non-surgical treatment of Class III malocclusion in adults: two case reports. J Orthod 2005; 32(2): 89-97. [http://dx.doi.org/10.1179/146531205225020952] [PMID: 15994982]

[4] Karakis D, Kaymak D, Dogan A. The evaluation of maximum bite force in the occlusal rehabilitation of patient with Angle Class III malocclusion: a case report. J Adv Prosthodont 2013; 5(3): 364-8. [http://dx.doi.org/10.4047/jap.2013.5.3.364] [PMID: 24049580]

[5] Hardy DK, Cubas YP, Orellana MF. Prevalence of angle class III malocclusion: a systematic review and meta- analysis. Open J Epidemiol 2012; 2: 75-82.

[http://dx.doi.org/10.4236/ojepi.2012.24012]

[6] Soh J, Sandham A, Chan YH. Occlusal status in Asian male adults: prevalence and ethnic variation. Angle Orthod 2005; 75(5): 814-20. [PMID: 16279828]

[7] Zurfluh MA, Kloukos D, Patcas R, Eliades T. Effect of chin-cup treatment on the temporomandibular joint: a systematic review. Eur J Orthod 2015; 37(3): 314-24.

[http://dx.doi.org/10.1093/ejo/cju048] [PMID: 25179261]

[8] Ritucci R, Nanda R. The effect of chin cup therapy on the growth and development of the cranial base and midface. Am J Orthod Dentofacial Orthop 1986; 90(6): 475-83. [http://dx.doi.org/10.1016/0889-5406(86)90107-1] [PMID: 3466528]

[9] Sugawara J. Clinical practice guidelines for developing Class III malocclusion. In: Nanda R, Ed. Biomechanics and Esthetic Strategies in Clinical Orthodontics. US: Saunders 2005; pp. 211-63. [http://dx.doi.org/10.1016/B978-0-7216-0196-0.50016-3]

[10] Chatzoudi MI, Ioannidou-Marathiotou I, Papadopoulos MA. Clinical effectiveness of chin cup treatment for the management of Class III malocclusion in pre-pubertal patients: a systematic review and meta-analysis. Prog Orthod 2014; $15: 62$. [http://dx.doi.org/10.1186/s40510-014-0062-9] [PMID: 25679781]

[11] De Clerck HJ, Proffit WR. Growth modification of the face: A current perspective with emphasis on Class III treatment. Am J Orthod Dentofacial Orthop 2015; 148(1): 37-46. [http://dx.doi.org/10.1016/j.ajodo.2015.04.017] [PMID: 26124026]

[12] Watkinson S, Harrison JE, Furness S, Worthington HV. Orthodontic treatment for prominent lower front teeth (Class III malocclusion) in children. Cochrane Database Syst Rev 2013; 9(9): CD003451.

[http://dx.doi.org/10.1002/14651858.CD003451.pub2] [PMID: 24085611]

[13] Sterne JAC, Higgins JPT, Reeves BC, et al. On behalf of the development group for ACROBAT-NRSI. A Cochrane Risk of Bias Assessment Tool for Non-randomized Studies of Interventions (ACROBAT- NRSI), Version 1.0.0, 2014 September 24; [accessed 2015 November 27] Available from: http://www.riskofbias.info

[14] Miyajima K, McNamara JA Jr, Sana M, Murata S. An estimation of craniofacial growth in the untreated Class III female with anterior crossbite. Am J Orthod Dentofacial Orthop 1997; 112(4): 425-34. [http://dx.doi.org/10.1016/S0889-5406(97)70051-9] [PMID: 9345155]

[15] Kim JH, Viana MA, Graber TM, Omerza FF, BeGole EA. The effectiveness of protraction face mask therapy: a meta-analysis. Am J Orthod Dentofacial Orthop 1999; 115(6): 675-85.

[http://dx.doi.org/10.1016/S0889-5406(99)70294-5] [PMID: 10358251]

[16] Ngan P. Early treatment of Class III malocclusion. Semin Orthod 2005; 11: 140-5. [http://dx.doi.org/10.1053/j.sodo.2005.04.007]

[17] Arman A, Toygar TU, Abuhijleh E. Profile changes associated with different orthopedic treatment approaches in Class III malocclusions. Angle Orthod 2004; 74(6): 733-40.

[PMID: 15673133]

[18] Tuncer BB, Kaygisiz E, Tuncer C, Yüksel S. Pharyngeal airway dimensions after chin cup treatment in Class III malocclusion subjects. J Oral Rehabil 2009; 36(2): 110-7. [http://dx.doi.org/10.1111/j.1365-2842.2008.01910.x] [PMID: 19522895]

[19] Akin M, Ucar FI, Chousein C, Sari Z. Effects of chincup or facemask therapies on the orofacial airway and hyoid position in Class III subjects. J Orofac Orthop 2015; 76(6): 520-30. [http://dx.doi.org/10.1007/s00056-015-0315-3] [PMID: 26446505]

[20] Lin HC, Chang HP, Chang HF. Treatment effects of occipitomental anchorage appliance of maxillary protraction combined with chincup traction in children with Class III malocclusion. J Formos Med Assoc 2007; 106(5): 380-91. 
[http://dx.doi.org/10.1016/S0929-6646(09)60323-5] [PMID: 17561473]

[21] Barrett AA, Baccetti T, McNamara JA Jr. Treatment effects of the light-force chincup. Am J Orthod Dentofacial Orthop 2010; 138(4): 468-76.

[http://dx.doi.org/10.1016/j.ajodo.2008.12.024] [PMID: 20889053]

[22] Abdelnaby YL, Nassar EA. Chin cup effects using two different force magnitudes in the management of Class III malocclusions. Angle Orthod 2010; 80(5): 957-62.

[http://dx.doi.org/10.2319/022210-110.1] [PMID: 20578869]

[23] Sakamoto T, Iwase I, Uka A, Nakamura S. A roentgenocephalometric study of skeletal changes during and after chin cup treatment. Am J Orthod 1984; 85(4): 341-50. [http://dx.doi.org/10.1016/0002-9416(84)90191-X] [PMID: 6608880]

[24] Abu Alhaija ES, Richardson A. Long-term effect of the chincap on hard and soft tissues. Eur J Orthod 1999; 21(3): 291-8. [http://dx.doi.org/10.1093/ejo/21.3.291] [PMID: 10407538]

[25] Alarcón JA, Bastir M, Rosas A, Molero J. Chincup treatment modifies the mandibular shape in children with prognathism. Am J Orthod Dentofacial Orthop 2011; 140(1): 38-43. [http://dx.doi.org/10.1016/j.ajodo.2009.10.046] [PMID: 21724085]

[26] Deguchi T, McNamara JA. Craniofacial adaptations induced by chincup therapy in Class III patients. Am J Orthod Dentofacial Orthop 1999; 115(2): 175-82.

[http://dx.doi.org/10.1016/S0889-5406(99)70346-X] [PMID: 9971929]

[27] Wendell PD, Nanda R, Sakamoto T, Nakamura S. The effects of chin cup therapy on the mandible: a longitudinal study. Am J Orthod 1985; 87(4): 265-74. [http://dx.doi.org/10.1016/0002-9416(85)90001-6] [PMID: 3857003]

[28] Alarcón JA, Requena MA, Delgado AC, González E, Martín C. Association between changes in soft and hard tissue after early chin cup treatment. J Orofac Orthop 2015; 76(3): 225-39.

[http://dx.doi.org/10.1007/s00056-015-0286-4] [PMID: 25929711]

[29] Gökalp H, Kurt G. Magnetic resonance imaging of the condylar growth pattern and disk position after chin cup therapy: a preliminary study. Angle Orthod 2005; 75(4): 568-75. [PMID: 16097225]

(C) Mousoulea et al.; Licensee Bentham Open

This is an open access article licensed under the terms of the Creative Commons Attribution-Non-Commercial 4.0 International Public License (CC BY-NC 4.0) (https://creativecommons.org/licenses/by-nc/4.0/legalcode), which permits unrestricted, non-commercial use, distribution and reproduction in any medium, provided the work is properly cited. 